\title{
Ionic Runoff as a Way to Determine the Degree of Karst Denudation (Case Study Jasov Plateau, Slovak Karst, Slovakia)
}

\author{
Alena Gessert ${ }^{1, *(D)}$, Imrich Sládek ${ }^{1}\left(\mathbb{D}\right.$, Veronika Straková ${ }^{2}$, Mihály Braun ${ }^{3}$, Enikő Heim ${ }^{3}$, Andrea Czébely ${ }^{3}$ \\ and László Palcsu ${ }^{3}$ \\ 1 Institute of Geography, Faculty of Natural Sciences, P.J. Šafárik University, 04001 Košice, Slovakia; \\ imrich.sladek@upjs.sk \\ 2 Museum Betliar, Slovak National Museum, 04921 Betliar, Slovakia; veronika.strakova@snm.sk \\ 3 Hertelendi Laboratory of Environmental Studies, Institute for Nuclear Research, Hungarian Academy of \\ Sciences, H-4026 Debrecen, Hungary; braun.mihaly@atomki.mta.hu (M.B.); heimeniko@isotoptech.hu (E.H.); \\ czebelyandrea@isotoptech.hu (A.C.); palcsu.laszlo@atomki.mta.hu (L.P.) \\ * Correspondence: alena.gessert@upjs.sk; Tel.: +421-55-234-2255
}

Citation: Gessert, A.; Sládek, I.; Straková, V.; Braun, M.; Heim, E.; Czébely, A.; Palcsu, L. Ionic Runoff as a Way to Determine the Degree of Karst Denudation (Case Study Jasov Plateau, Slovak Karst, Slovakia). Water 2021, 13, 1449. https:// doi.org/10.3390/w13111449

Academic Editor: Francesco Fiorillo

Received: 15 April 2021

Accepted: 20 May 2021

Published: 21 May 2021

Publisher's Note: MDPI stays neutral with regard to jurisdictional claims in published maps and institutional affiliations.

Copyright: (c) 2021 by the authors. Licensee MDPI, Basel, Switzerland. This article is an open access article distributed under the terms and conditions of the Creative Commons Attribution (CC BY) license (https:// creativecommons.org/licenses/by/ $4.0 /)$.

\begin{abstract}
Estimation of the catchment area of a karst spring is not possible in all areas for various reasons. The Slovak Karst is protected by the highest degree of protection and karst springs are used as a source of drinking water for the second largest city in Slovakia, Košice. From this reason, no results on ionic runoff or chemical denudation have been published from this area and the most appropriate way to obtain information about the denudation rate is to determine the ionic runoff. This paper provides an overview of ionic runoff results based on sampling and analysis of karst water from six springs in the period November 2013-October 2016 (three hydrological years) and periodic measurements. Springs have significantly fluctuated flow rates from $0 \mathrm{~L} / \mathrm{s}$ in summer and autumn up to $192 \mathrm{~L} / \mathrm{s}$, and episodic events during the snow melting and heavy rain in the spring of 2013 are also known (more than $380 \mathrm{~L} / \mathrm{s}$ ). The total value of ionic runoff for the area of $40,847 \mathrm{~m}^{3} / \mathrm{y} \cdot \mathrm{km}^{2}$ is comparable with the Vracanska Plateau in Bulgaria, which lies at a similar altitude and with a similar amount of precipitation.
\end{abstract}

Keywords: ionic runoff; denudation rate; Slovak karst; karst springs

\section{Introduction}

Chemical denudation, or the uniform lowering of the karst surface, is a dominant karstification mechanism that is also widely recognized as the primary cause of the creation of surface and underground karst forms. That is why the topics of ionic runoff and chemical denudation are two of the classic problems of karstology. The rate of lowering of a karst surface due to bedrock dissolution is commonly referred to as the denudation rate [1-3]. This can be expressed in several ways. It is most often expressed as the amount of material removed in mm over a period of 1000 years (also called Bubnoff unit, [4]), or in $\mathrm{m}^{3} / \mathrm{km}^{2} /$ year. The term ionic runoff [5] has been used to denominate the amount of dissolved rock mass transported by waterways (not depending on the area).

Corbel's equation was the first to be used to measure the degree of denudation in the karst [6]. Since Corbel initially reported the issue of regional denudation distribution, many different field methods have been proposed to solve the problem. One of the direct methods is the calculation based on limestone plates or measurement using a micro-erosion meter (MEM). Indirect methods are, e.g., hydrochemical measurements, geomorphological research and recent methods using cosmogenic nuclides (mainly ${ }^{36} \mathrm{Cl}$ ) [7]. Each of these methods has its advantages and disadvantages that limit its use. The denudation rate calculated from tablet measurements was several times (4-5) lower than the denudation rate obtained from the hydrochemical data. Using this method, precipitation was found to be the most important factor in the rate of denudation. Recently, this method was used by Plan [8], 
who found that the denudation rates obtained from tablet measurements $(10-30 \mathrm{~mm} / \mathrm{ka})$ are 2-8 times lower than those obtained from solute flow measurements. A micro-erosion meter (MEM) [9] is used to directly measure surface reduction. Using MEM, it was found that in addition to climatic differences, denudation rates were also related to the slope and lithological properties of the rock [10]. The degree of denudation can also be estimated from the height of pedestals (e.g., erratic boulders) protected from corrosion or emerging veins of "insoluble" rocks. However, a reliable estimate of their growth time is needed. Lauritzen [11] presented a pedestal growth model taking into account condensation corrosion under boulders and the boulder shading effect, concluding that the total denudation rate should be $25-80 \%$ higher than the rate calculated directly from pedestal height and growth time. The latest methods are based on cosmogenic ${ }^{36} \mathrm{Cl}$ produced in calcite from ${ }^{40} \mathrm{Ca}$ [12]. The main processes involved are Ca spallation and different muon reactions [7]. Denudation continuously alters the shielding of the rock; therefore, the denudation rates can be estimated by the model of shielding history.

As ionic runoff is very closely related to the evaluation of the denudation rate, we present an extended overview of previous works. Among the most important works we can mention Corbel [6], which dealt with factors affecting denudation and considers this a sign of the development of karst in different climatic regimes. Smith and Newson [13] focused on the dissolution rate based on chemical and mechanical erosion. Priesnitz [14] found a positive relationship between limestone solubility and yield, which was also confirmed by [5,15]. Appelo and Postma [16] drew attention to the issue of karst denudation in their monograph on the topic of groundwater geochemistry. Gabrovšek [17] presented a simple mathematical model of the denudation rate in karst. The carbonate denudation rate was reconstructed in dependence on temperature and precipitation [18]. In the Polish Sudetes, the intense karst denudation in a crystalline basin with small positions of marble was studied [19]. The seasonal variability of chemical export rates was concluded and there was a positive correlation with surface runoff discharge in the Houzhai karst basin in the southwest of China [20].

In a comprehensive work on the chemical denudation of karst [5], the author presented the ionic runoff values from 14 localities in Europe and Asia and argued that ionic runoff is primarily influenced by mineralization and discharge in various climatic regions of the Earth and in various types of karst e.g., alpine, Mediterranean, karst basins, cold and tropical climate, etc. [21-24].

From the neighboring Czech Republic, more studies are known $[25,26]$ which dealt with changes in the intensity of denudation in the Moravian Karst or investigated different dissolution rates for different karst rocks [27].

In Slovak conditions, the monitoring of denudation and corrosion studies around the caves were performed [28]. A pioneer in the research of denudation was Droppa [29-31], who focused on the determination of the denudation rate mainly in the karst basins of the Low Tatras. Two studies [32,33] have explored the weight loss of limestone tablets at two experimental sites in the Slovak Karst. Both have provided the most in-depth analysis to date of the karst denudation and the first results from the Slovak Karst area. Differences in the denudation rate may be caused by the influence of the content of the dolomitic component on the karstifying of limestones [34].

The plateaus of the Slovak Karst are among the best developed karst areas in Europe, yet ionic runoff and karst denudation rates have not been explored in depth (and no results have been published so far). The area is located in the Dfb climate zone (cold, humid continental with the temperature of the coldest month below $0{ }^{\circ} \mathrm{C}$ ), at the interface of the continental and oceanic climates, in terms of altitude at the border between the lowland and mountain climate [35].

Denudation helps us to understand the rate of formation of karst forms and thus the development of karst areas. As it occurs in different areas or climatic zones, it is not possible to determine a global figure that would cover all karst areas of the world. Therefore, we would like to contribute to this overview with the missing new information about ionic 
runoff (and thus denudation) from the area of the Slovak Karst as an example of a plain in the temperate zone of Europe. These results allow comparison with other localities and thus contribute to the study of regional differences or similarities and, at the same time, to the influence of individual factors on the different degree of denudation.

Since the recharge areas of the individual springs of the Jasov Plateau have not yet been delineated, the most appropriate way to obtain more detailed data about this area is to determine the ionic runoff, which is a non-invasive method and is based on relatively simple measurements of spring discharge and electrical conductivity. The delineation of the catchment areas by dye tracing is not possible due to the highest degree of protection of the area and the use of one of the important springs as the main source of drinking water for the surrounding settlements and partly for the second largest city in Slovakia, Košice. That is the main reason why we chose this method.

This paper provides an overview of ionic runoff results based on regular sampling and study of karst water (one per month) from six springs of the Jasov Plateau in the Slovak Karst in the period November 2013-October 2016 (three hydrological years). We also included springs in the secondary calculations that were not analyzed regularly but by expedition, or data on them are known from the literature. The aim of this paper is to provide a comprehensive picture of the ionic runoff from the entire Jasov Plateau $\left(65 \mathrm{~km}^{2}\right)$ and the approximate rate of denudation based on the method of calculating ionic runoff, thus filling the information gap from a typical plateau karst area in the middle of Europe. As similar research on ionic runoff or karst denudation has not yet been conducted in this area, these are pilot results that can still be worked with.

\section{Study Area}

\subsection{Geographical and Climatic Setting}

The Slovak Karst represents the best developed karst territory of Slovakia with a perfectly developed surface and underground phenomenon. This karst region is situated in the eastern part of southern Slovakia, representing the largest and most typical karst area of Slovakia (over $800 \mathrm{~km}^{2}$ ), extending to the northern Hungarian Aggtelek Karst (Figure 1). The altitude difference between the canyon- and gorge-like valleys and the plateau surface is $\sim 400 \mathrm{~m}$ a.s.l. [36].

The Jasov Plateau is the easternmost plateau of the karst area and is unique from a natural, historical perspective but also from the human relationship to the karst relief (the plateau surface undergoes anthropogenic modification). The largest area of the plateau is situated between 500 and $700 \mathrm{~m}$ a.s.l. (circa $60 \%$ ) and the mean surface inclination is $9^{\circ} \mathrm{E}-\mathrm{SE}$. As much as $70 \%$ of the area falls into this category. The direction of inclination is identical to the general immersion of the whole Slovak Karst. Due to the proximity to the second largest city of Slovakia, Košice, the plateau has been the subject of numerous geological, geomorphological, hydrological, and speleological research in the past (e.g., [36-41]).

The Jasov Plateau is also rich in well-developed underground karst phenomena, where 77 known caves have been invented so far [41]. The longest of them were created by fluvio-karstic activity. Skalistý potok Cave $(8215 \mathrm{~m})$ is the longest known underground river in the Slovak Karst with three genetic levels. Drienovec Cave $(1558 \mathrm{~m})$ and Kunia Abyss (933 m) are important fluviokarstic caves on the southern slope and foot of the plain. At the eastern foot are the entrances to Jasov Cave (3924 m) and Moldava Cave (3070 m) (all length data) [42].

The mean annual air temperature of the area is $8-9{ }^{\circ} \mathrm{C}$ [43] (average summer air temperature $18-19{ }^{\circ} \mathrm{C}$, winter air temperature -1 to $-2{ }^{\circ} \mathrm{C}$ ). The Jasov Plateau receives 601-700 mm precipitation per annum, whereby the highest amount of precipitation falls in spring and summer (spring 151-200 mm, summer 201-250 mm, autumn 119-150 mm and in winter 59-100 mm). In the Jasov Plateau area, a dense land cover predominates, consisting mainly of beech forests thriving mainly on leptosols and rubified rendzinas. In the north and west of the territory, there are remnants of pastures and meadows as a memento of agricultural activity on the plain in the second half of the 20th century. 

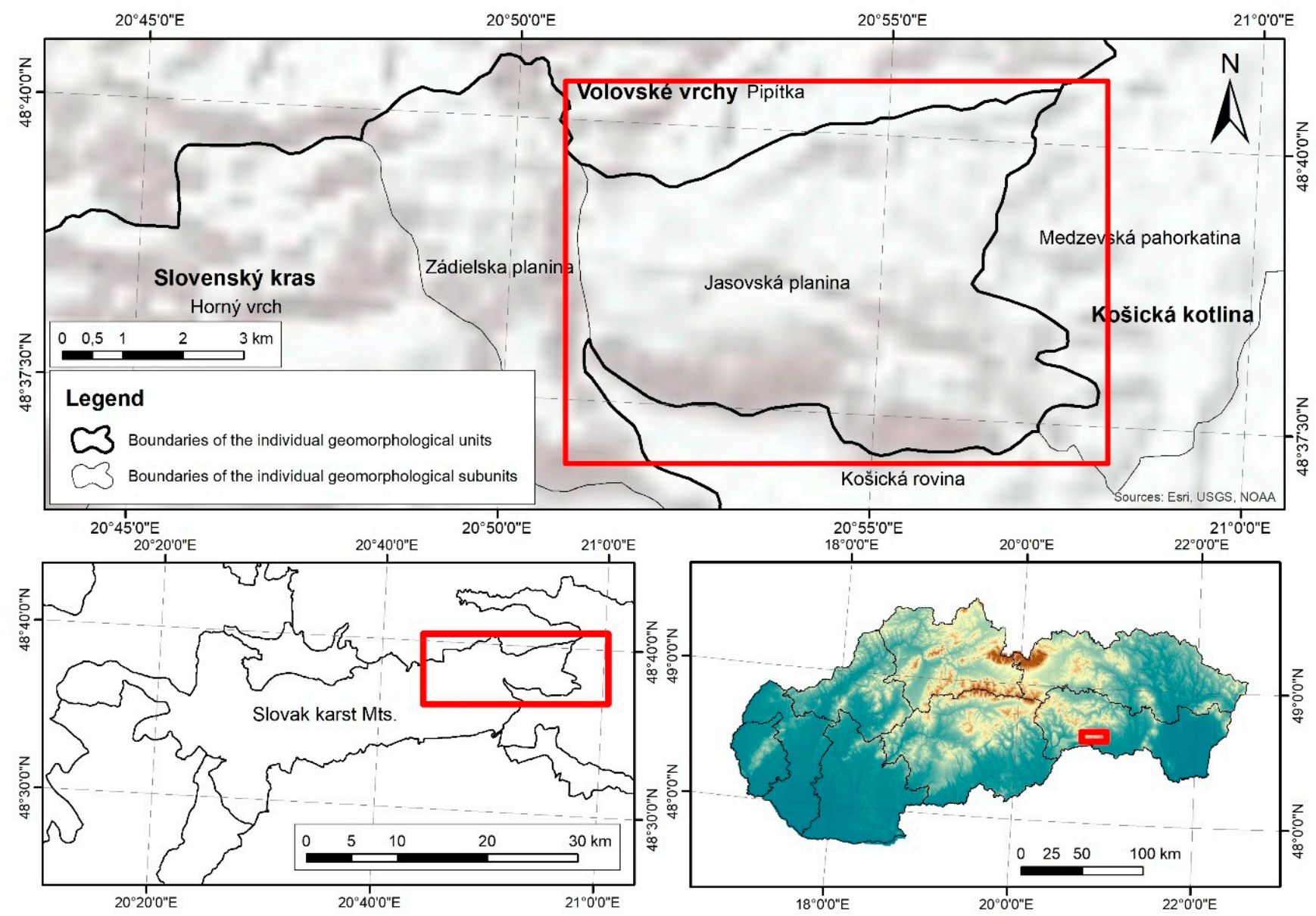

Figure 1. Position of the study area within Slovakia, Slovak Karst, and Jasov Plateau.

\subsection{Geological and Hydrogeological Settings of the Jasov Plateau}

The area is comprised of a complex of Mesozoic rocks. The Silicicum Nappe [44] is represented here by Triassic and Jurassic rocks, and Upper Cretaceous and Tertiary and Quaternary sediments. Triassic rocks represent a substantial part of the karstified carbonates, and most of them are the Gutenstein, Steinalm, Wetterstein reef and lagoon limestones, Waxenec, and Dachstein limestones. Jurassic rocks are Adnetic, Hierlatz limestones with small local occurrences in the nearby valley of Miglinc, and in the same valley we can find Cretaceous Miglinc limestones. Paleogene is represented by the Šomod formation and Drienovec conglomerates (interfering on the base of the neogene).

The Jasov Plateau is divided by a well-defined fault, the Rožňava deep fault (direction NW and SE), into two parts of different sizes (Figure 2). This fault is clearly visible in the Miglinc valley, but at the same time it forms the boundary between two partial tectonic structures. Several faults with E-W direction are involved in the formation of the Turña basin and separate it from the Mesozoic Jasov Plateau. Consequently, dislocation structures of a downward displacement and rearward character play an important role [45].

There is no surface runoff in the studied area, and rainwater infiltrates directly into the karstified Mesozoic carbonates (Figure 3). The outflow of karst waters occurs in several ways [46]. The springs at the level of the local base are typical by high discharge in the south and east of the studied area-Drienovec, Drienovec Cave, and Teplica. A spring with a combined seepage flow is, e.g., Sv. Ladislav (in the central part of the surface). 


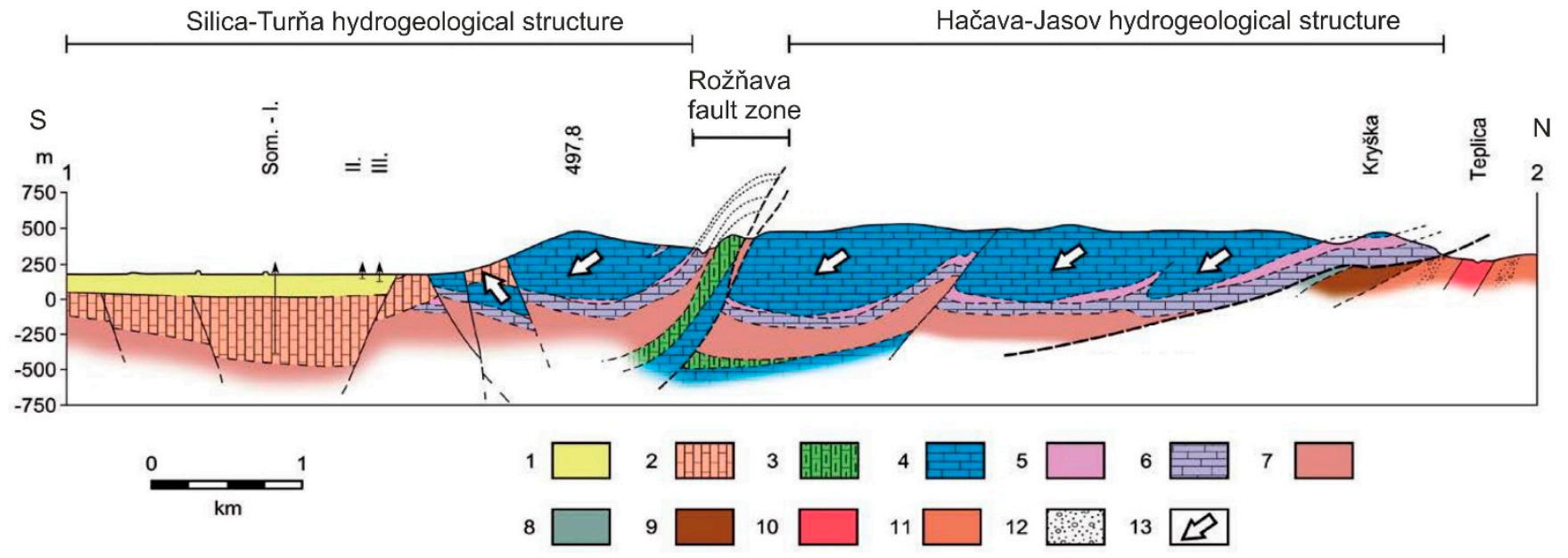

Figure 2. Geological profile of the Jasov Plateau, Reprinted with permission from ref. [47]. Copyright 2012, Zacharov. Profile: Tertiary: 1—clastic sediments, carbonaceous clays, lignite (Miocene); 2-limestone, shales, conglomerates, Šomody formation (Eocene-Oligocene); Mesozoic: 3-limestones, marls, breccias undistinguished (Upper Triassic-Jurassic); 4-Waxeneck, Wetterstein and Steinalm limestones (Middle-Upper Triassic); 4-Gutenstein dolomites (Upper Triassic); 6Gutenstein limestones (Upper Triassic); 7—shales, sandstones (Lower Triassic); 8-phyllites, crystalline limestones (TriassicJurassic); Paleozoic: 9-metamorphosed sandstones (Permian); 10—metarhyolites (Permian); 11—phyllites (Permian); 12-metaconglomerates (Permian); 13 — direction of ground water flow.

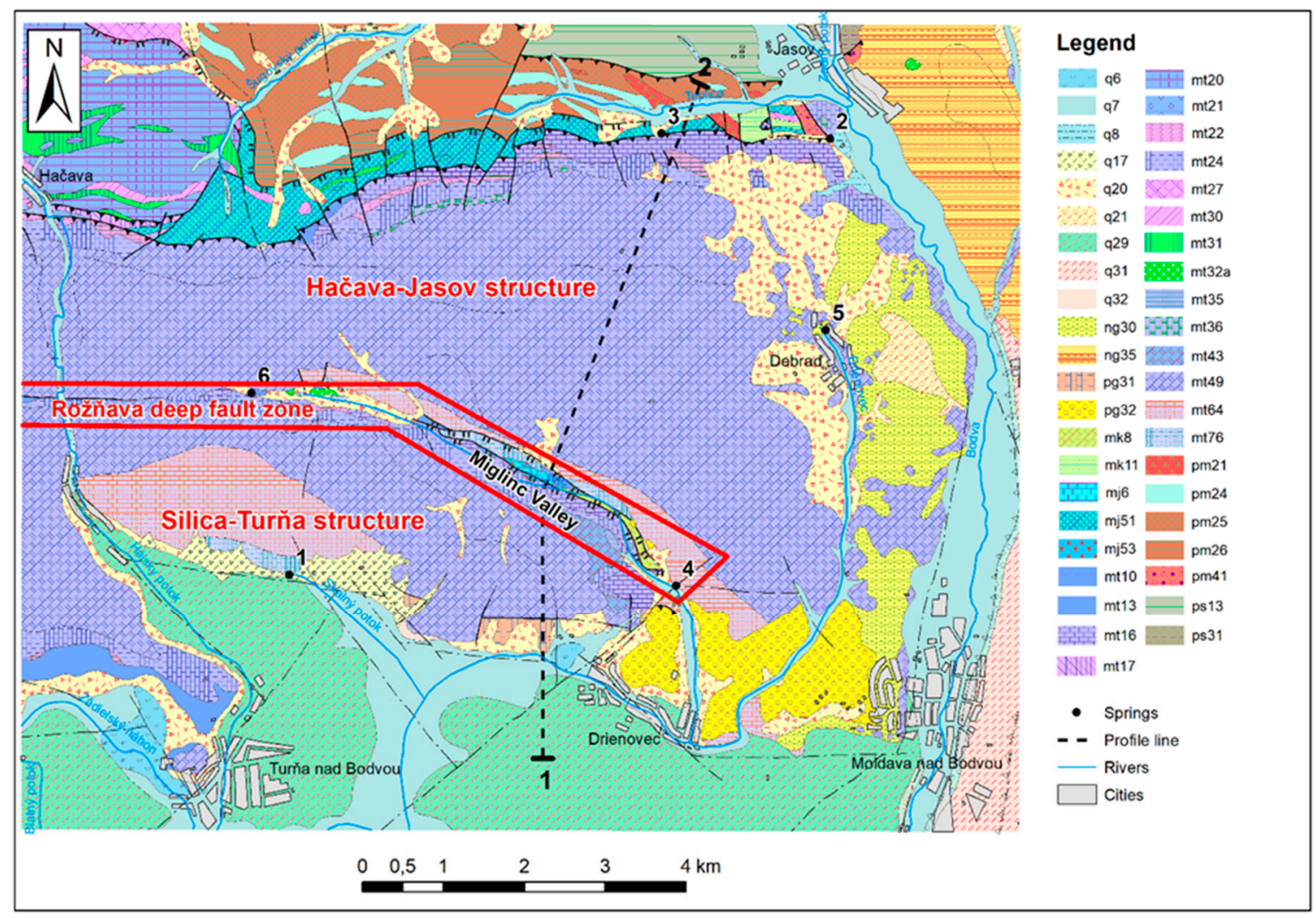

Figure 3. Geological map of the Jasov Plateau Reprinted with permission from ref. [48]. Copyright 2013, State Geological Institute of D. Štúr. Explanation: Quaternary: Holocene: q6—organic sediments: moors and flood plain peats, q7—fluvial sediments: alluvial loams, q8-proluvial sediments: loams and sandy loams, Pleistocene/Holocene: q17-deluvialproluvial sediments: loamy and loamy-stony alluvial fans, q20—deluvial sediments: loamy-stony debris, q21—deluvial 
sediments: sandy and sandy-loamy gravels, Pleistocene: q29-proluvial sediments: loamy and sandy gravels of alluvial fans, q31—eolic-deluvial sediments: loessy loams, q32—eolic sediments: loess and sandy loess, Tertiary: Neogene: ng30— Poltár Formation: variegated clays, gravels, sands, ng35-Sečovce Formation: variegated clays, carbonaceous clays, lignite, Paleogene: pg31-limestones, carbonatic conglomerates, pebbly mudstones, pg32—Somody Beds: Drienovec conglomerates (carbonatic conglomerates), Mesozoic: Cretaceous: mk8-Miglinc limestones: white massive limestones, mk11-Gombasek Beds: dark shales and sandstones, Jurassic: mj6-Allgäu Beds: dark marly limestones and marls, mj51—dark-grey and black phyllites with metasandstones, mj53 — variegated basal breccias and limestones, Adnet and Hierlatz limestones, TRIASSIC: mt10—Bódvaszilas Beds: variegated sandstones and shales, mt13—Szin Beds: shales, limestones, dolomites, rauvaks, mt16-Gutenstein Beds: Gutenstein limestones, dark-grey and black limestones, mt17-Gutenstein dolomites: dark-grey dolomites, dolomite breccias, $\mathrm{mt}$ 20-Honce limestones: pale crystalline limestones, $\mathrm{mt} 21$-red detritic limestones and conglomerates, mt22-Ramsau dolomites: grey dolomites, mt24-Steinalm limestones: organodetritic limestones, sometimes dolomites, mt27—grey-green and light shaly crystalline limestones, mt30—Dúbrava Formation: chloritesericite phyllites with intercalations of crystalline limestones and metabasic rocks (predominantly metatuffites), mt31Dúbrava Formation: metabasic rocks (predominantly glaucophanites), mt32a—serpentinites, mt35—Schreyeralm limestones: pink nodular limestones, mt36-Nádaska limestones: pink bedded limestones, mt43-Reifling and "Pseudoreifling" limestones: grey bedded cherty limestones, mt49-Wetterstein limestones: organodetritic massive limestones, mt64Waxeneck (Tisovec) limestones, mt76-Dachstein limestones: Riff and Lagoonal organodetritic limestones, Paleozoic: Permian: pm21-metaryolites, metadacites and their volcanoclastics, pm24-metamorphosed oligomictic conglomerates, pm25-metasandstones, pm26-sericite and chlorite-sericite phyllites, with chloritoid, pm41—polymictic conglomerates, Early Paleozoic: ps13-laminated sericitic-chloritic phyllites, ps31-quartz metagreywackers with local intercalations of quartz phylites. 1-Skalistý potok Spring, 2-Pekná dievčina Spring, 3-Teplica Spring, 4-Drienovec Cave Spring, 5-Sv. Ján Spring, 6-Kozia studňa Spring.

The area is part of two hydrogeological structures, namely Hačava-Jasov and SilicaTurňa [49]. These are separated by the tectonic line of the Miglinc valley, in which several smaller springs originate. The Hačava-Jasov structure is slightly inclined to the south and the Middle Triassic limestones lie directly on the Paleozoic. The investigated springs Teplica, the spring of the Drienovec Cave, Pekná dievčina (Pretty girl Spring), Kozia studňa (Goat Well Spring) and Sv. Ján (St. John Spring) are situated in the southeastern part of the study area (Figure 3). The Silica-Turňa hydrogeological structure represents a Triassic limestone-dolomitic complex synclinically deposited on Lower Triassic rocks. Here, karst springs have relatively high discharge. In this study, we monitored the Skalistý potok-Vinica Spring (connected to the Skalistý potok Cave, which is permanent and reaches the highest discharge).

Springs characterized by both shallow and deep circulation show a similar hydrochemistry, indicating that the carbonate massif is completely water-logged [50]. In the Hačava-Jasov hydrogeological structure, the carbonates of the Jasov Plateau, the Bodva river alluvium (to the east), and the carbonates in their subsoil form a common aquifer connected by the water circulation, hampering the precise delineation of the catchment areas.

\subsection{Studied Springs}

A total of six permanent and ephemeral springs were investigated in this study. These springs are located in both hydrogeological structures and at the above-mentioned tectonic fault in the Miglinc valley (to ensure the diversity of the nature of the springs). All of them have been described in more detail by [51].

Skalistý potok Spring is a permanent spring, draining the Silica-Turňa HG (hydrogeological) structure, and is the spring with the highest discharge of this structure. It is situated on the southern foothill of the Jasov Plateau at the altitude of $210 \mathrm{~m}$ a.s.l., where water emerges from the contact zone of deluvial-proluvial sediments and fluvial sediments of a river plain.

Pekná Dievčina Spring is on the eastern foothill of Jasov in the Hačava-Jasov HG structure. This ephemeral spring is situated at an altitude of $268 \mathrm{~m}$ a.s.l., only $5 \mathrm{~m}$ above the Bodva River plain. Water emerges where the Gutenstein dolomite complex meets proluvial sediments. 
Teplica Spring is the largest spring of the Hačava-Jasov HG structure on the northern foothill of the plateau at the altitude of $325 \mathrm{~m}$ a.s.l. It emerges at the contact zone of deluvial debris accumulation and Gutenstein dolomite.

Drienovec Cave Spring is typical by high discharge and is situated the contact of structures near the tectonic line. It flows out from the entrance of a $1.5 \mathrm{~km}$ long active fluviokarstic cave at the altitude of $254 \mathrm{~m}$ a.s.l. located in Waxeneck limestone.

Sv. Ján Spring emerges in the Hačava-Jasov HG structure on a fluvial planation surface and forms the Drienovec River at the altitude of $267 \mathrm{~m}$ a.s.l. It is situated $80 \mathrm{~m}$ above the Bodva River plain in the contact zone of Poltár Formation and Wetterstein limestone.

Kozia studňa Spring is located in the upper part of the Miglinc valley at the altitude of $574 \mathrm{~m}$ a.s.1., directly in a large fault heading from SE to the NW separating HG structures. The area is characterized by a complex geological structure [44].

\section{Materials and Methods}

\subsection{Fieldwork and Sampling}

During the hydrological years 2013-2016, the discharge rate (using the FP 111 hydrometric wing, Global Water, Phoenix, AZ, USA), temperature, $\mathrm{pH}$, electrical conductivity (by Hanna HI 98129, Hanna Instruments, Woonsocket, RI, USA), and carbonate alkalinity (using the titrimetric kilt Aquamerck Alkalinity Test 1.11109.0001, Merck, Darmstadt, Germany) were measured in the field. Two water samples were taken monthly for further laboratory analyses to study the chemical composition of the spring. Major ion concentrations were analyzed on a Shimadzu UV-2600 UV-VIS spectrophotometer and a Metrohm TitrIC 7 chromatograph. Missing data are due to episodic spring and spring access restriction.

\subsection{Karst Water Characteristics}

Characterization coefficients represent an auxiliary criterion in solving the genesis of the chemical composition of water. For the characterization of the karstic water, we used the following coefficients according to the work [52]: $\mathrm{rMg} / \mathrm{rCa}, \mathrm{r}(\mathrm{Na}+\mathrm{K}) / \mathrm{r}(\mathrm{Ca}+\mathrm{Mg})$ for waters with carbonatogenic mineralization, $\mathrm{rHCO}_{3} / \mathrm{rCl}$ to determine the depth coefficient and $\mathrm{rNa} / \mathrm{rCl}$ to determine the origin of sodium.

The saturation index is one of the imbalance indices [52] and provides an indicator of the degree of water saturation relative to calcium carbonate. It can also be interpreted as a change in $\mathrm{pH}$ needed to achieve water balance. For the calculation of the saturation index the PHREEQC program was used [53].

It should be noted, however, that the proportion of ions in water, and therefore their relative ratio in water, is not only determined by the relative ratio of the respective ions in the rock environment, but is influenced by a number of other factors.

\subsection{Calculation of Ionic Runoff}

The measured and analyzed data were used to calculate ionic runoff following methods $[5,54]$ :

$$
\begin{gathered}
\mathrm{IR}=31.5 \times \mathrm{T} \times \mathrm{Q}(\mathrm{t} / \text { year }) \\
\mathrm{IR}=12.6 \times \mathrm{T} \times \mathrm{Q}\left(\mathrm{m}^{3} / \text { year }\right)
\end{gathered}
$$

$\mathrm{IR}$-ionic runoff $\mathrm{t}$ /year or $\mathrm{m}^{3} /$ year, $\mathrm{Q}$ - average discharge in $\mathrm{m}^{3} / \mathrm{s}$, and $\mathrm{T}$-total mineralization in $\mathrm{mg} / \mathrm{L}$ (TDS), and for the content of a particular ion, coefficient 31.5 was counted: $31.5 \times 10^{6}$-number of seconds in a year $\left(31.5 \times 10^{6} \mathrm{~g} / \mathrm{s}=31.5 \mathrm{t} /\right.$ year $), 12.6$ is the coefficient counted as $31.5 / 2.5=12.6$, where 2.5 is the average density of carbonates, sulphates and chlorides $\left(\mathrm{g} / \mathrm{cm}^{3}\right)$.

To calculate our results per unit area, we used $65 \mathrm{~km}^{2}$ area of the whole plateau with slopes [33]. Since there is no meteorological station in our surveyed area (Jasov Plateau), the total precipitation was calculated on the basis of data from 4 precipitation stations located near the surveyed area. These are the stations Moldava nad Bodvou, Jasov, Turňa 
nad Bodvou and Hačava. The Horton polygon method was used for the calculation of the Jasov Plateau precipitation, which consists of calculating the total precipitation as a weighted average of the total precipitation belonging to individual stations, the weights being considered to be the area belonging to the given station.

\section{Results}

The data obtained by direct field measurements as well as laboratory analysis were initially subjected to simple statistical analysis in the minimum, maximum, median, and mean ranges. Individual data for separate months and summary statistics are presented in the overview table (Supplementary Table S1).

\subsection{Hydrochemistry of the Karst Water}

Based on the characterization coefficient $\mathrm{r}(\mathrm{Na}+\mathrm{K}) / \mathrm{r}(\mathrm{Ca}+\mathrm{Mg})$, it can be stated that the karst water originates from a clearly karstic subsoil (coefficient less than 0.1). At two springs-Drienovec Cave (in 2014) and Kozia studňa (in 2016) — the rMg/rCa coefficient is greater than 0.1 and in two is 0.1 (Supplementary Table S1), indicating water from dolomitic limestone or mixed circulation. Both of these springs appear at the abovementioned tectonic fault, which separates the two hydrogeological structures. However, in most cases it is less than 0.1, which means that the water comes from pure limestone.

Based on the Piper diagram (Figure 4), the water from all springs is of the calciummagnesium-bicarbonate type. In all samples, weak acids predominate over strong acids and alkaline earth metals predominate over alkaline metals. The graph also shows that the carbonate hardness (secondary alkalinity) exceeds 50\%. The position of the samples in all graphs also indicates the calcite dissolution process.

We observe slightly lower carbonate alkalinity and electrical conductivity between 12/2013 and 02/2014 (and lower calcium content) compared to other months of the study period. These months also had higher precipitation than usual. Therefore, we consider in this case the change of the river basin boundary over time and thus also the chemical composition of the water, which is related to the geological diversity of the studied area and the potential occurrence of dolomites or dolomitic limestone lenses.

The coefficient $\mathrm{rHCO}_{3} / \mathrm{rCl}$ indicates that the hydrogeological structures of the springs are slightly different. All springs (except Pekná dievčina Spring) are half-opened structures, whereas Pekná dievčina is a half-closed structure. Sodium is mostly bound in $\mathrm{NaCl}$ in Drienovec Cave and Pekná dievčina springs, and in the other four springs (Skalistý potok, Teplica, Sv. Ján and Kozia studňa) it is also bound as $\mathrm{NaHCO}_{3}$.

Most values of the saturation index (Supplementary Table S2) indicate that the water is supersaturated with respect to $\mathrm{CaCO}_{3}$ and occasionally $\mathrm{CaCO}_{3}$ precipitate in the form of tufas was observed at Drienovec Cave Spring, Teplica Spring and Sv. Ján Spring.

From this, it was concluded that the karst water is enriched with chemical elements at depths where the main anion is usually $\mathrm{HCO}_{3}{ }^{-}$. Such mineralization is referred to as lithomorphic mineralization and can be correlated with the chemical-mineralogical composition of the rocks. The decisive process in the formation of this mineralization is the interaction of meteoric waters (rainwater, groundwater), the rock environment and to a lesser extent also the underground atmosphere.

The temperature of the springs (Figure 4) varied from $1.9^{\circ} \mathrm{C}$ to $15.5^{\circ} \mathrm{C}$ during the study period. The largest temperature fluctuations were recorded at the Kozia studňa Spring (min. $1.9^{\circ} \mathrm{C}$, max. $15.5^{\circ} \mathrm{C}$, average $8.7^{\circ} \mathrm{C}$ ), where water temperature was partially influenced by the air temperature and the artificial outlet and the precipitation temperature. Relatively large temperature fluctuations were recorded at the Pekná dievčina Spring, as well (min. $4.5^{\circ} \mathrm{C}$, max. $13.9^{\circ} \mathrm{C}$, average $10.5^{\circ} \mathrm{C}$ ). The highest average temperature was reached by Skalistý potok Spring at $11^{\circ} \mathrm{C}\left(\min .9^{\circ} \mathrm{C}\right.$, max. $\left.13^{\circ} \mathrm{C}\right)$.

$\mathrm{PH}$ values are very similar for all springs. During the monitoring period, $\mathrm{pH}$ values varied between 5.7 and 8.7, with average values between 7.4 and 7.9 (Figure 5). 


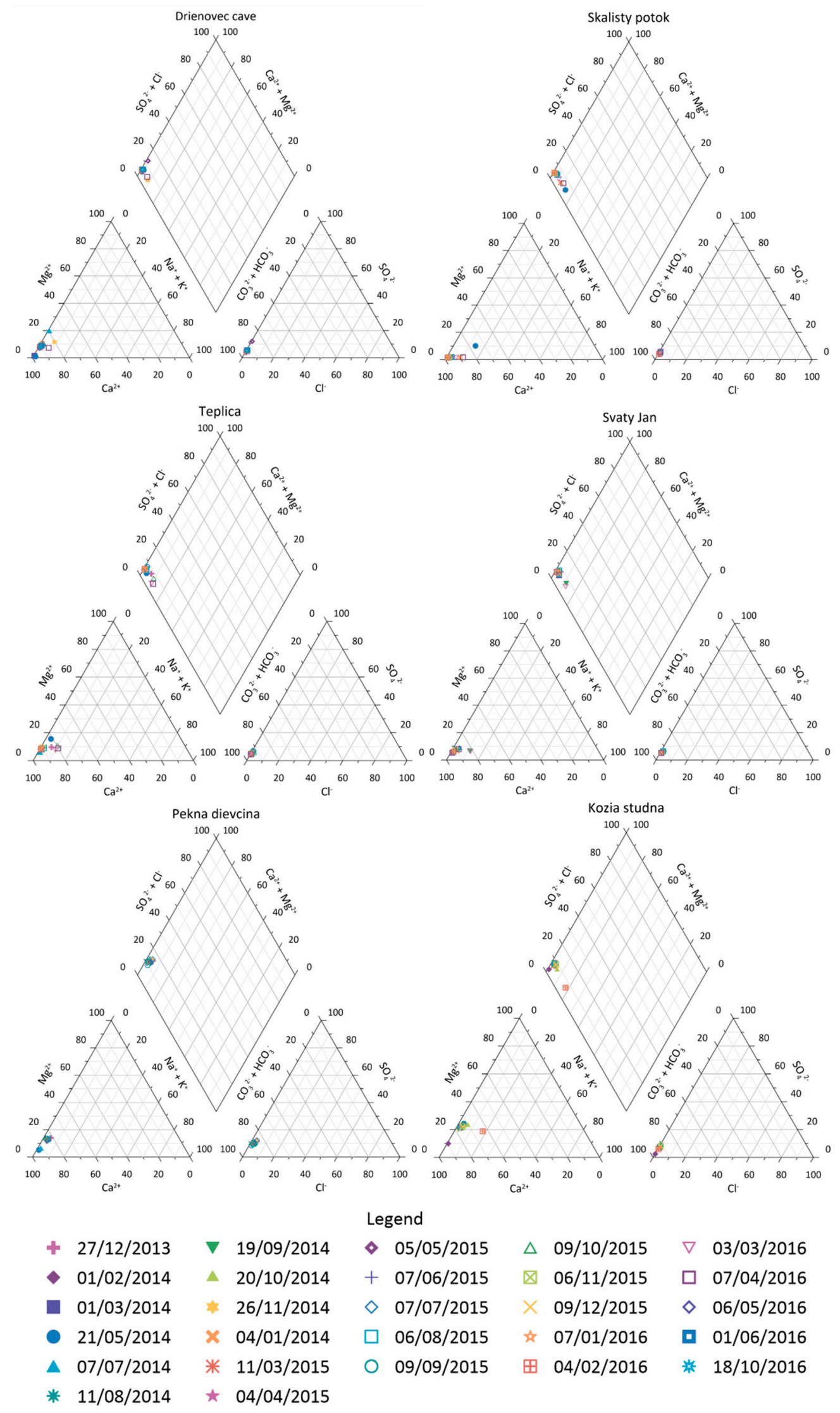

Figure 4. Piper plot of monitored springs. 

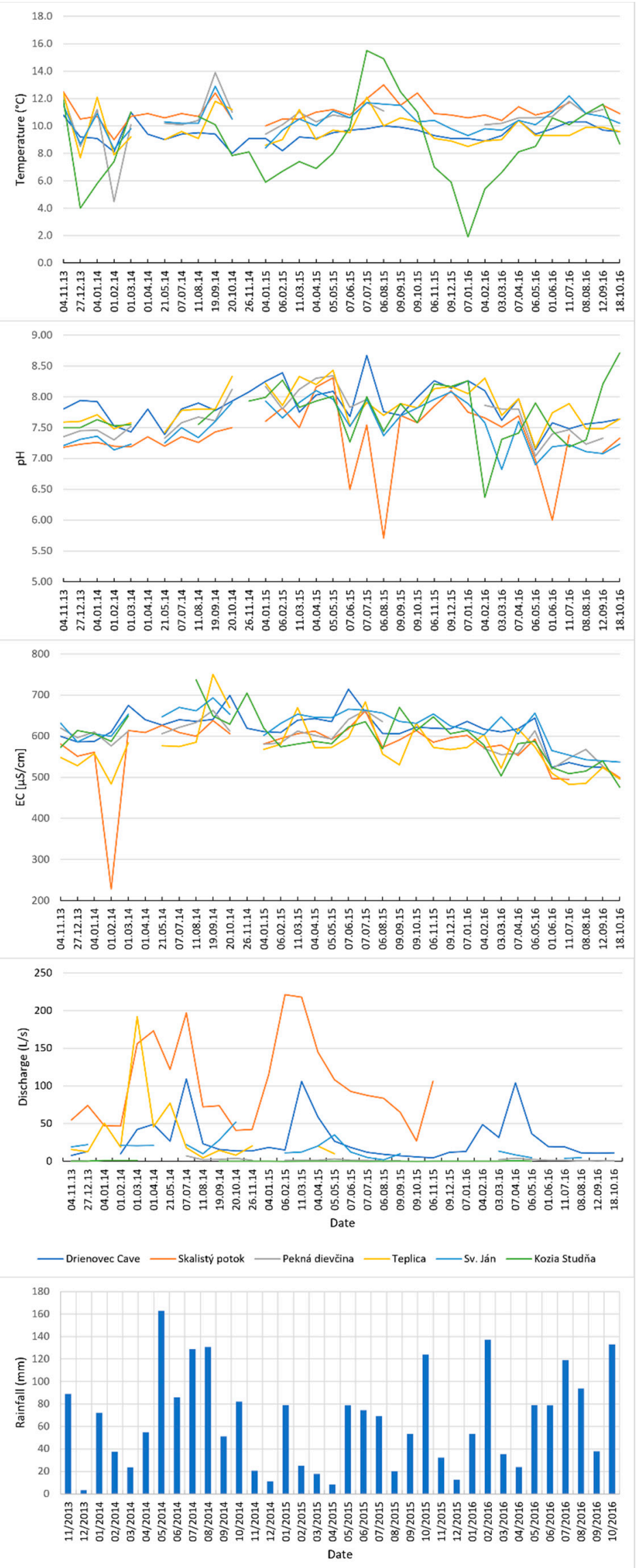

Figure 5. Main water parameters-temperature, $\mathrm{pH}$, electrical conductivity, discharge and rainfall. 
No large differences were seen in electrical conductivity (Figure 4). Slightly increased electrical conductivity occurs late in the summer months. Average electrical conductivity reached from 624 to $573 \mu \mathrm{S} / \mathrm{cm}$, but an extreme fluctuation was recorded on 1 February 2014, when it reached only at the Skalistý potok Spring $228 \mu \mathrm{S} / \mathrm{cm}$. Carbonate alkalinity varied between 6.2 and $6.9 \mathrm{mM} / \mathrm{L}$. The lowest average carbonate alkalinity for the whole period was measured at the source Pekná dievčina Spring, namely, 5.5.

\subsection{Ionic Runoff}

When evaluating ionic runoff, the Pulina methodology [5,54] based on TDS and discharge (described in detail in the methodology part) for individual springs over three hydrological years was used. A more detailed overview and statistical evaluation of the Jasov Plateau springs' ionic runoff, monitored by us and calculated in $\mathrm{t} /$ year and $\mathrm{m}^{3} /$ year, are given in Supplementary Table S2.

The total annual average ionic runoff (from hydrological years 2014-2016) from all monitored springs of the Jasov Plateau is $50.76 \mathrm{~g} / \mathrm{s}$, equal to $639.33 \mathrm{~m}^{3} /$ year, where individual springs account for:

(a) Skalistý potok $29.44 \mathrm{~g} / \mathrm{s}, 370.92 \mathrm{~m}^{3} /$ year,

(b) Pekná dievčina $0.55 \mathrm{~g} / \mathrm{s}, 6.88 \mathrm{~m}^{3} /$ year,

(c) Teplica $7.50 \mathrm{~g} / \mathrm{s}, 94.50 \mathrm{~m}^{3} /$ year,

(d) Drienovec Cave $8.34 \mathrm{~g} / \mathrm{s}, 105.08 \mathrm{~m}^{3} /$ year,

(e) Sv. Ján $4.85 \mathrm{~g} / \mathrm{s}, 61.11 \mathrm{~m}^{3} /$ year,

(f) Kozia studňa $0.067 \mathrm{~g} / \mathrm{s}, 0.84 \mathrm{~m}^{3} /$ year.

Based on these results, we investigated the relationship between ionic runoff and precipitation, but there is no demonstrable immediate correlation. The authors in $[51,55]$ described this area and monitored the springs' mean residence time of karst water based on tritium analysis in the years 2013-2016. The annual mean tritium concentration between 2012 and 2016 varied between 8.2 and 9.8 TU. The isotope composition of precipitation does not reflect that of infiltrating water because the summer contribution is smaller than that of the other seasons due to evaporation and transpiration. Estimating the tritium concentrations of recharge water between 7 and 8 TU in the years 2013-2016, and using the radioactive decay law, the mean residence time of most of the Jasov Plateau springs is obtained as between 0 and 2 years [55].

\section{Discussion}

The relationship between the discharge of individual springs and the ionic runoff for the whole period has been examined. These graphs show that there is a clear linear dependence of the ionic runoff on discharge (based on the formula for ionic runoff). However, in some months the values are above the trend line, and we observed the most significant ones at the source Skalistý potok. The spring months of 2014 were characterized by unusually high precipitation (extreme was May 2014, total $162 \mathrm{~mm}$ ), which caused an increased amount of unsaturated water circulating in the Jasov Plateau massif, and the consequent increased ionic runoff not completely correlated with discharge (Figure 6). During this period, it is one of the isolated cases where the precipitation affected the discharge almost immediately. Although the relationship between ionic runoff and discharge is directly expressed by the formula, on a more detailed view over the months, there are slight deviations from the trend line that express an increased or decreased effect of TDS on total ionic runoff (during higher or lower discharge). 


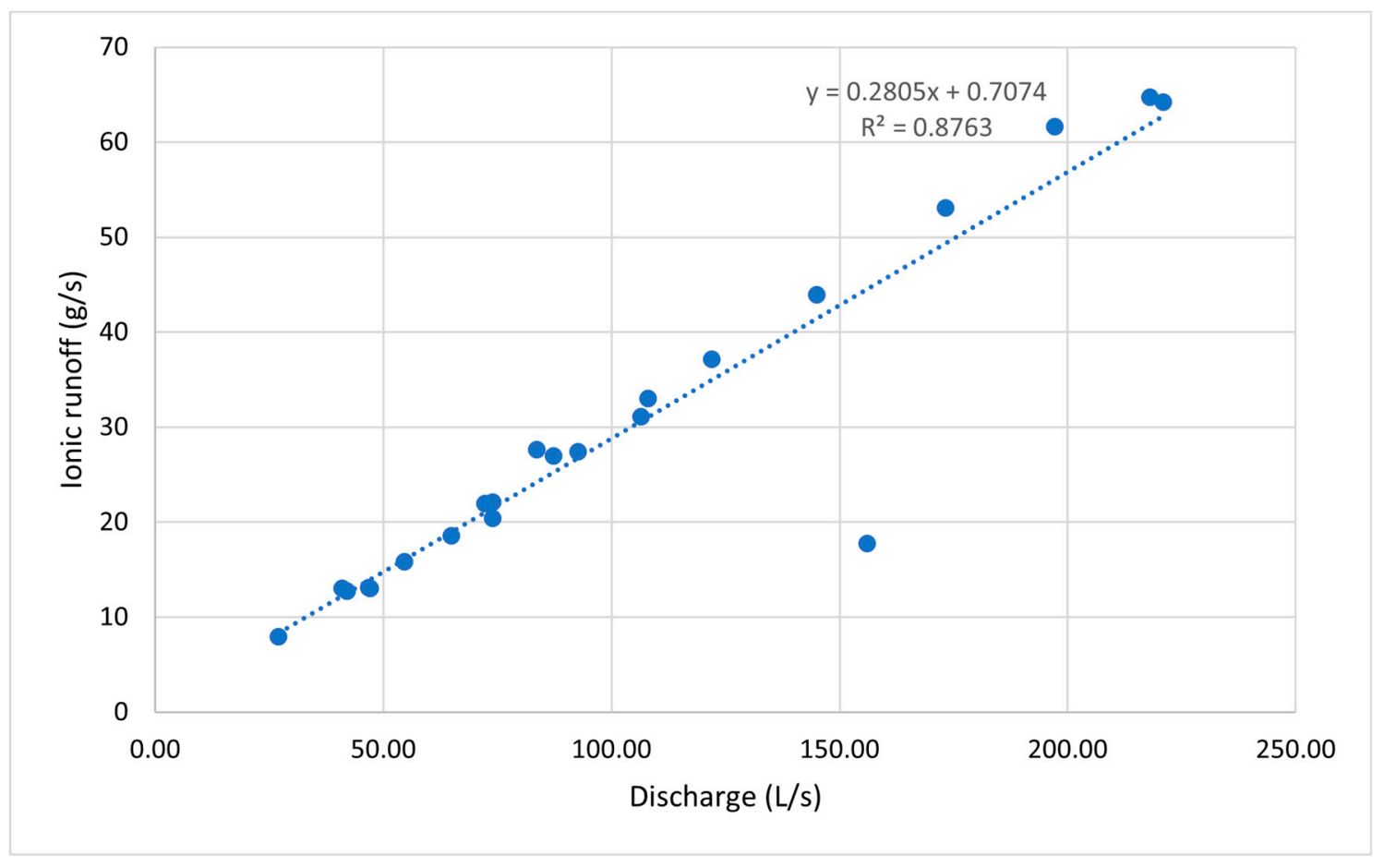

Figure 6. Correlation between ionic runoff and discharge of Skalistý potok Spring.

Based on our measured data from six regularly monitored springs, the average value of ionic runoff for the Jasov Plateau in the Slovak Karst is $639.33 \mathrm{~m}^{3} /$ year. Drienovec main Spring is used for drinking water supply and therefore there is relatively exact information about its TDS and discharge from free available data (www.shmu.sk, accessed on 1 April 2021). However, to make our results as comprehensive as possible, we decided to calculate the ionic runoff value based on data obtained during measurements in 2013 from other outlets in this area (total mineralization and average yield), giving us a relatively accurate view of the total ionic runoff from the Jasov Plateau. In our opinion, these complete results (measured and available data) are then comparable with existing data from other parts of the world. If we only took into account regularly measured results, we would probably include only half of the real ionic runoff. Thus, the total ionic runoff based on measured and recalculated data from the whole Jasov Plateau represents in the spring period of the year $2664.939 \mathrm{~m}^{3}$ /year (where periodic springs are also active). The measured and calculated values are listed in the following Table 1.

Figure 7 presents the relationship between precipitation and average ionic runoff from all measured Jasov Plateau springs. It clearly shows the relationship towards the season (and thus evapotranspiration and the amount of water available for karst processes). In winter, when evapotranspiration is minimal, even the minimum amount of precipitation is reflected in the ionic runoff (e.g., 01-02/2015). During the growing season, a large single amount of precipitation is needed to manifest itself in the ionic runoff at least minimally (e.g., 05-06/2014). This shows how important the evapotranspiration is and thus the vegetation period and the type of vegetation cover for the level of the ionic runoff during the hydrological year. 
Table 1. Average discharge, TDS and ionic runoff overview based on measurements and available data.

\begin{tabular}{|c|c|c|c|c|}
\hline & Area & Average TDS (mg/L) & $\begin{array}{c}\text { Average Discharge } \\
(\mathrm{L} / \mathrm{s})\end{array}$ & IR $\left(\mathrm{m}^{3} /\right.$ Year $)$ \\
\hline Monitored Springs & - & 357.5 & 176.3 & 639.3 \\
\hline Drienovec Main Spring & Drienovec & 421 & 184.0 & 983.4 \\
\hline Hatiny Spring & Hatiny & 218 & 1.0 & 2.7 \\
\hline Dvojičky Spring & Miglinc Valley & 330.5 & 0.1 & 4.2 \\
\hline Perlová studňa Spring & North Slope & 238 & 1.0 & 2.9 \\
\hline Teplica Cave Spring & Jasov-Teplica & 304.2 & 55.5 & 194.3 \\
\hline $\begin{array}{c}\text { Teplica Hydrological } \\
\text { Object }\end{array}$ & Jasov-Teplica & 300.2 & 25.6 & 89.4 \\
\hline Mikei Spring & Debrad' & 132.1 & 36.3 & 141.4 \\
\hline Čuporka Spring & Debrad' & 351.3 & 47.7 & 195.4 \\
\hline Čuporka II. Spring & Debrad' & 209.2 & 2.4 & 9.6 \\
\hline Skalistý potok Cave & South slope & 226.7 & 50.8 & 163.0 \\
\hline Gusto Cave & Háj Valley & 106.6 & 47.3 & 147.6 \\
\hline Travertine Spring & Háj Valley & 185.1 & 3.2 & 8.7 \\
\hline Travertine Cave & Háj Valley & 103.6 & 14.0 & 41.9 \\
\hline Triple Spring & Miglinc Valley & 295.2 & 6.2 & 21.9 \\
\hline Stano's Place & Plateau surface & 65.1 & 0.9 & 3.2 \\
\hline P 07 & Miglinc Valley & 114.1 & 0.4 & 0.8 \\
\hline P 09 & Miglinc Valley & 115.1 & 0.5 & 1.4 \\
\hline P 11 & Miglinc Valley & 320.2 & 1.1 & 3.9 \\
\hline P 12 & Miglinc Valley & 242.2 & 0.7 & 2.1 \\
\hline P 14 & Miglinc Valley & 155.1 & 0.5 & 0.5 \\
\hline P 18 & Miglinc Valley & 311.2 & 1.8 & 6.2 \\
\hline P 21 & Miglinc Valley & 292.2 & 0.1 & 0.4 \\
\hline Pod stromom Spring & Teplica-Jasov & 117.1 & 0.5 & 0.5 \\
\hline Total & - & - & 657.8 & 2664.9 \\
\hline
\end{tabular}

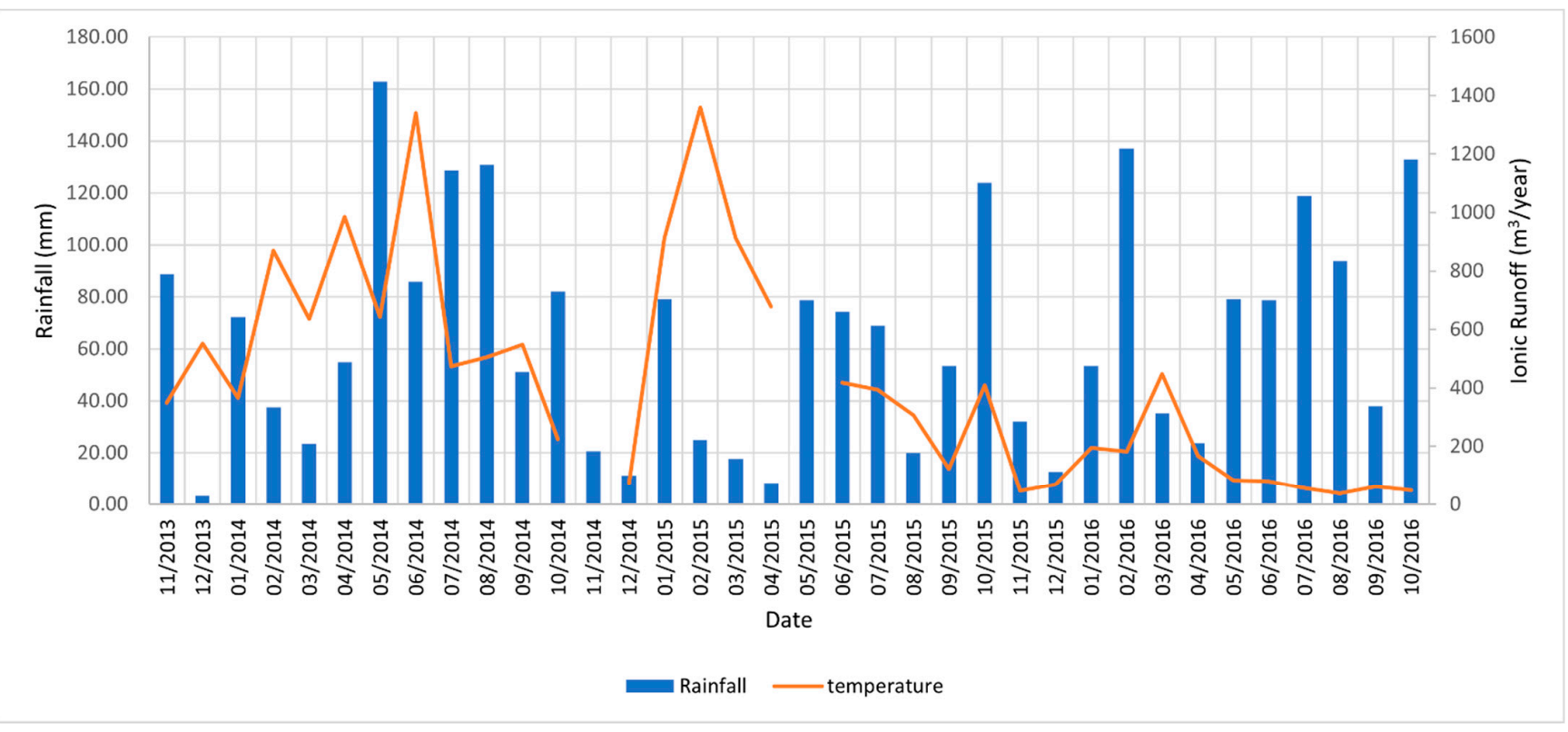

Figure 7. Relationship of rainfall and average ionic runoff of Jasov Plateau.

The measured ionic runoff and spring discharge on the Jasov Plateau were compared to other European sites where previous study results were available $[5,23]$ by the same method (localities and their main characteristics are listed in Table 2). These experimental sites were chosen mainly based on their location, altitude, average annual precipitation 
and temperature, and the character of the karst area (lowland, middle and high mountains). The ionic runoff is directly expressed through the discharge and mineralization of karst water. However, these variables enter the calculation with varying intensity. Based on Figure $8 \mathrm{a}, \mathrm{b}$, it can be stated that ionic runoff is directly proportional to the discharge of karst springs $\left(R^{2}=0.8493\right)$ and the overall mineralization also plays an important role here $\left(R^{2}=0.4254\right)$, but it is secondary. The spring with the highest discharge is Ljubljanica (Notranski kras, Slovenia), with an average discharge of about $71 \mathrm{~m}^{3} \mathrm{~s}^{-1}$ and the highest ionic runoff (cannot be displayed in the graph, Table 2). Sites such as Presles Plateau, Wiercica-Julianka, and Vichren (in the right part of Figure 8a) are typical of high discharge of permanent springs situated here. This causes a significant obvious correlation between discharge and ionic runoff. In contrast, a weak correlation appears between IR and mineralization (Figure 8b).

Table 2. Ionic runoff in karst areas of Europe [5,23].

\begin{tabular}{|c|c|c|c|c|c|c|c|c|c|c|}
\hline \multirow{2}{*}{ Experimental Site } & 1 & 2 & 3 & Year & $\mathrm{S}$ & $\mathbf{Q}$ & $q$ & TDS & IR & IR/S \\
\hline & a.s.l. & ${ }^{\circ} \mathrm{C}$ & $\mathrm{mm}$ & & $\mathrm{km}^{2}$ & $\mathrm{~m}^{3} \mathrm{~s}^{-1}$ & $\mathrm{~L} \cdot \mathrm{s}^{-1} \cdot \mathrm{km}^{-2}$ & $\mathrm{mg} / \mathrm{L}$ & $\mathrm{m}^{3} / \mathrm{y}$ & $\mathrm{m}^{3} / \mathrm{y} \cdot \mathrm{km}^{2}$ \\
\hline \multicolumn{11}{|c|}{ Sudetes (Poland) } \\
\hline Snieżnik & 840 & 4.5 & 1000 & 1966-1970 & 0.22 & 0.004 & 16.0 & 169 & 7.4 & 33.036 \\
\hline Krowiarki Mts. & 450 & 7 & 600 & 1965-1966 & 1.40 & 0.010 & 7.0 & 300 & 37 & 26.429 \\
\hline Kaczawskie Mts. & 400 & 7.2 & 500 & 1965-1966 & 2.81 & 0.019 & 5.5 & 306 & 37.9 & 13.488 \\
\hline \multicolumn{11}{|c|}{ Jura Krakowsko-Częstochowska (Poland) } \\
\hline Wiercica-Julianka & 270 & 6.7 & 660 & 1968 & 183.7 & 1.440 & 7.8 & 175 & 3160 & 17.202 \\
\hline Wiercica-Janów & 320 & 6.7 & 660 & 1968 & 25.20 & 0.263 & 10.4 & 185 & 610 & 24.206 \\
\hline \multicolumn{11}{|c|}{ Tatras (Poland) } \\
\hline Kościeliska-Kiry Valley & 1450 & 1.8 & 1550 & 1965-1970 & 29.20 & 1.080 & 37.0 & 105 & 1429 & 48.938 \\
\hline Zlewnia Lodowe Źródło & 1500 & 1.5 & 1580 & 1965-1970 & & 0.300 & 37.0 & 100 & 378 & \\
\hline \multicolumn{11}{|c|}{ Vercors (France) } \\
\hline Plateau Presles & 900 & 7.2 & 1600 & 1967-1968 & 25.80 & 1.000 & 38.8 & 200 & 2520 & 97.674 \\
\hline \multicolumn{11}{|c|}{ Julian Alps (Slovenia) } \\
\hline Triglav & 1800 & -1.7 & 2120 & 1965 & & 0.250 & 60.0 & & 204.7 & \\
\hline \multicolumn{11}{|c|}{ Plateau Kras (Slovenia) } \\
\hline $\begin{array}{c}\text { Notranski } \\
\text { Kras-Ljubljanica }\end{array}$ & 900 & 7.2 & 1600 & 1962-1969 & 1915 & 71.00 & 37.0 & 194 & $173.5 .10^{3}$ & 90.601 \\
\hline \multicolumn{11}{|c|}{ Piryn (Bulgaria) } \\
\hline Vichren Massif & 1900 & 3.5 & 1500 & 1967,1969 & 73.00 & 2.309 & 31.6 & 118 & 3433 & 47.027 \\
\hline \multicolumn{11}{|c|}{ Stara Planina (Bulgaria) } \\
\hline Vracanska Planina & 800 & 9.0 & 800 & 1967,1969 & 52.50 & 0.550 & 10.5 & 300 & 2010 & 38.286 \\
\hline \multicolumn{11}{|c|}{ Dobrudza (Bulgaria) } \\
\hline Black Sea Coast & 100 & 12.5 & 440 & 1967,1969 & 59.00 & 0.325 & 5.5 & 332 & 1360 & 23.051 \\
\hline \multicolumn{11}{|c|}{ Caucasus (Russia) } \\
\hline Alek Massif & 800 & 9.5 & 2800 & 1970 & 11.00 & 0.715 & 65.0 & 170 & 1531 & 139.182 \\
\hline \multicolumn{11}{|c|}{ Slovakia } \\
\hline $\begin{array}{c}\text { Slovak Karst, Jasov } \\
\text { Plateau }\end{array}$ & 600 & 8.0 & 600 & 2013-2016 & 65.00 & 0.660 & 10.1 & 355.2 & 2664.94 & 40.847 \\
\hline
\end{tabular}

1—altitude, 2-temperature, 3-precipitation, S-area, Q-discharge, q-specific runoff, TDS—-total dissolved solid, IR-ionic runoff. 


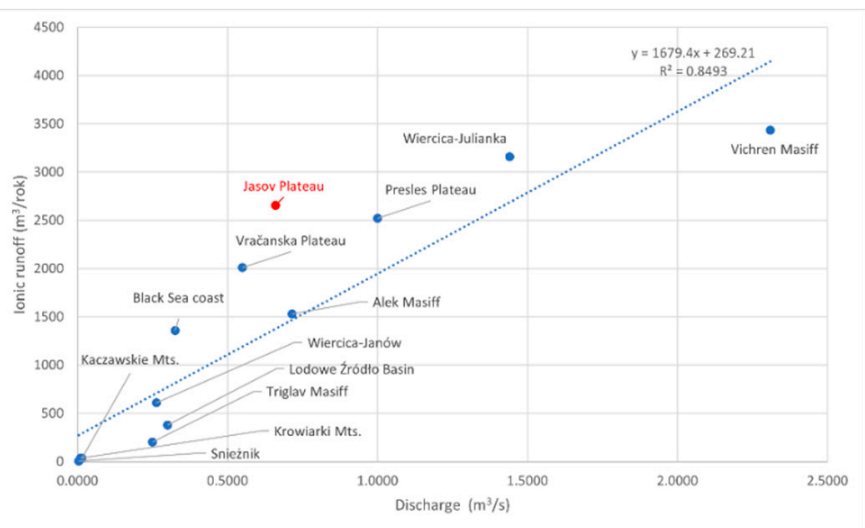

(a)

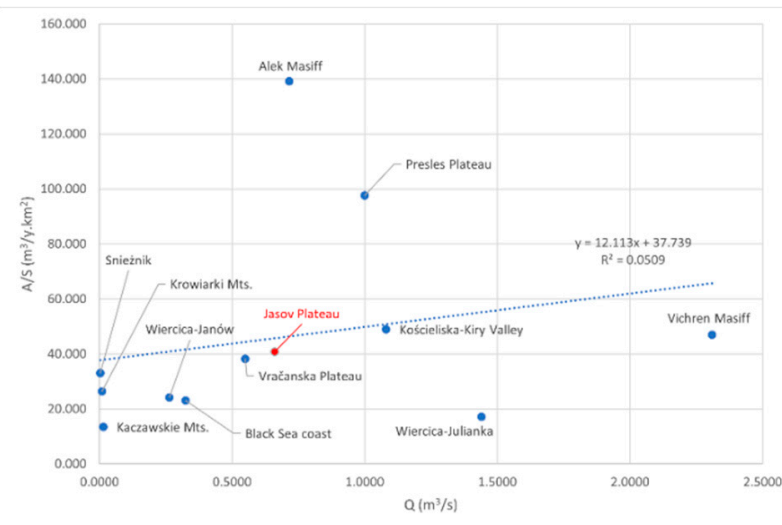

(b)

Figure 8. Relationship of ionic runoff and discharge (a) and mineralization (b). Study areas of $[5,23]$ and Slovak Karst, localities described in Table 2.

In terms of the relationship between discharge and yearly ionic runoff from $\mathrm{km}^{2}$ (A/S), the Jasov Plateau reaches a value of $40.847 \mathrm{~L} \cdot \mathrm{s}^{-1} \cdot \mathrm{km}^{-2}$, which is just below the trend curve (Figure 9). Locations above the trend lines (Massif Alek-Caucasus, Plateau PreslesFrance) are areas with the highest specific runoff from all analyzed springs (Presles$38.8 \mathrm{~L} \cdot \mathrm{s}^{-1} \cdot \mathrm{km}^{-2}$, Alek $-65 \mathrm{~L} \cdot \mathrm{s}^{-1} \cdot \mathrm{km}^{-2}$, listed in Table 2 ).

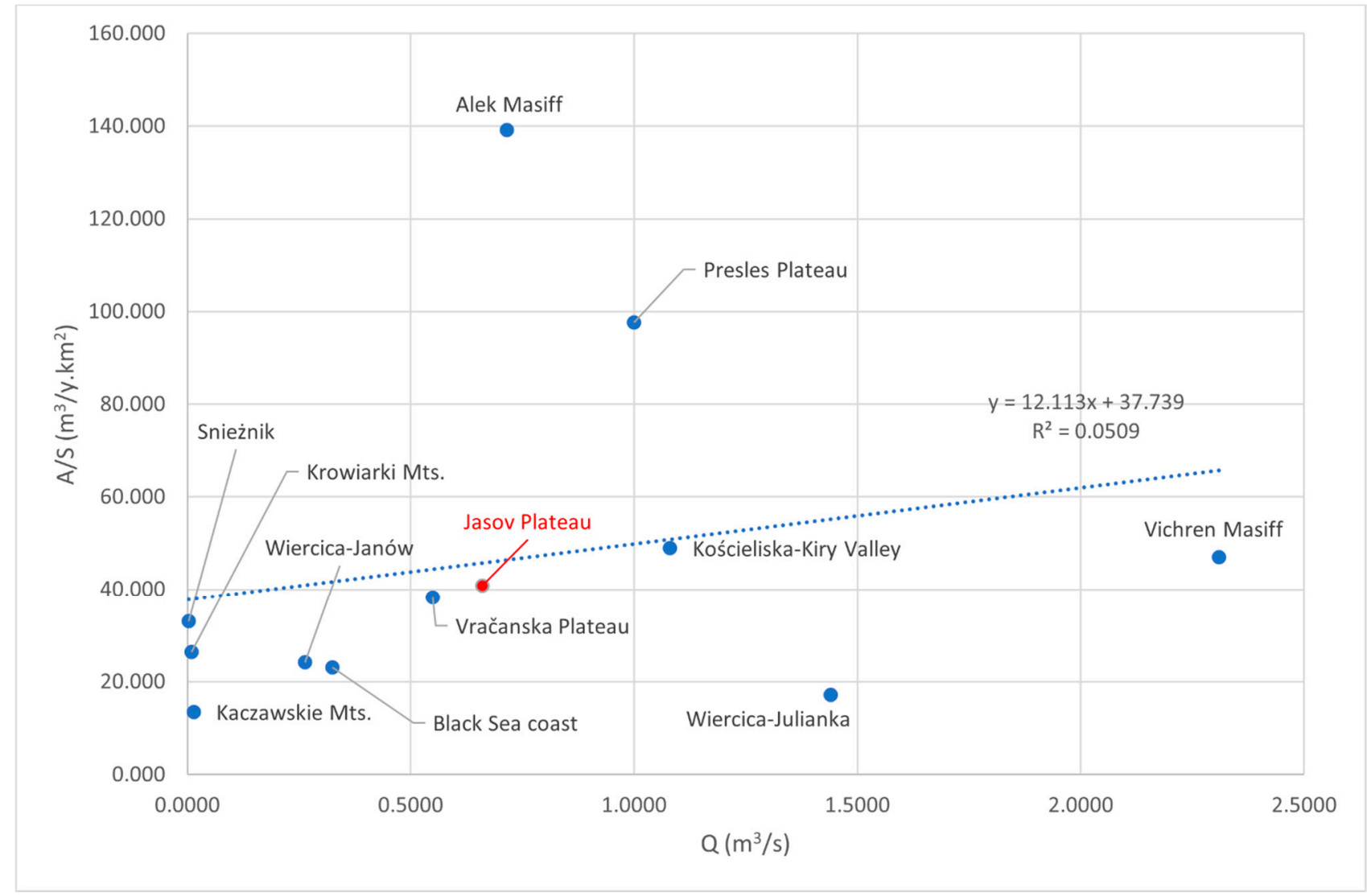

Figure 9. Relationship of discharge and A/S (ionic runoff/area). Study areas of $[5,23]$ and Slovak Karst, localities described in Table 2.

The value of the denudation rate for the Jasov Plateau is $40,847 \mathrm{~mm} / 1000$ years. Compared to previous research in the area of Slovakia-Low Tatras, the rate of denudation is 
slightly lower. Demänovská dolina (average annual rainfall $1250 \mathrm{~mm}$ ) reaches denudation values of $46.8-55.3 \mathrm{~mm} / 1000$ years [29], but it is an area of alpine karst. The area of the Moravian Karst (Czech Republic) reaches values of 6-25 mm/1000 [27,56,57]. It can therefore be said that in the temperate zone with similar climatic conditions, our results are comparable.

The most important factors for ionic runoff based on the results and monitoring of the basic relationships are climatic ones. In the area of the Slovak Karst as a temperate zone, the decisive factor is the discharge of karst springs, which is significantly affected by precipitation $\left(R^{2}=0.8721\right.$, Figure 10). The interval of the water residence time in the karst massif is affected by the structural, textural properties and the lithology of the bedrock and the karst conduit system [54]. This area is built of high quality limestone (as we described in more detail in the geological characteristics of the area). The amount of precipitation in our territory is directly linked to the season, when the largest amount of precipitation in the Slovak Karst falls in the summer months (July-August) and is reflected in fluctuations in the discharge of springs. In addition, the maximum is reached in the spring during snow melting (March-April) and causes episodic floods at all springs in the area.

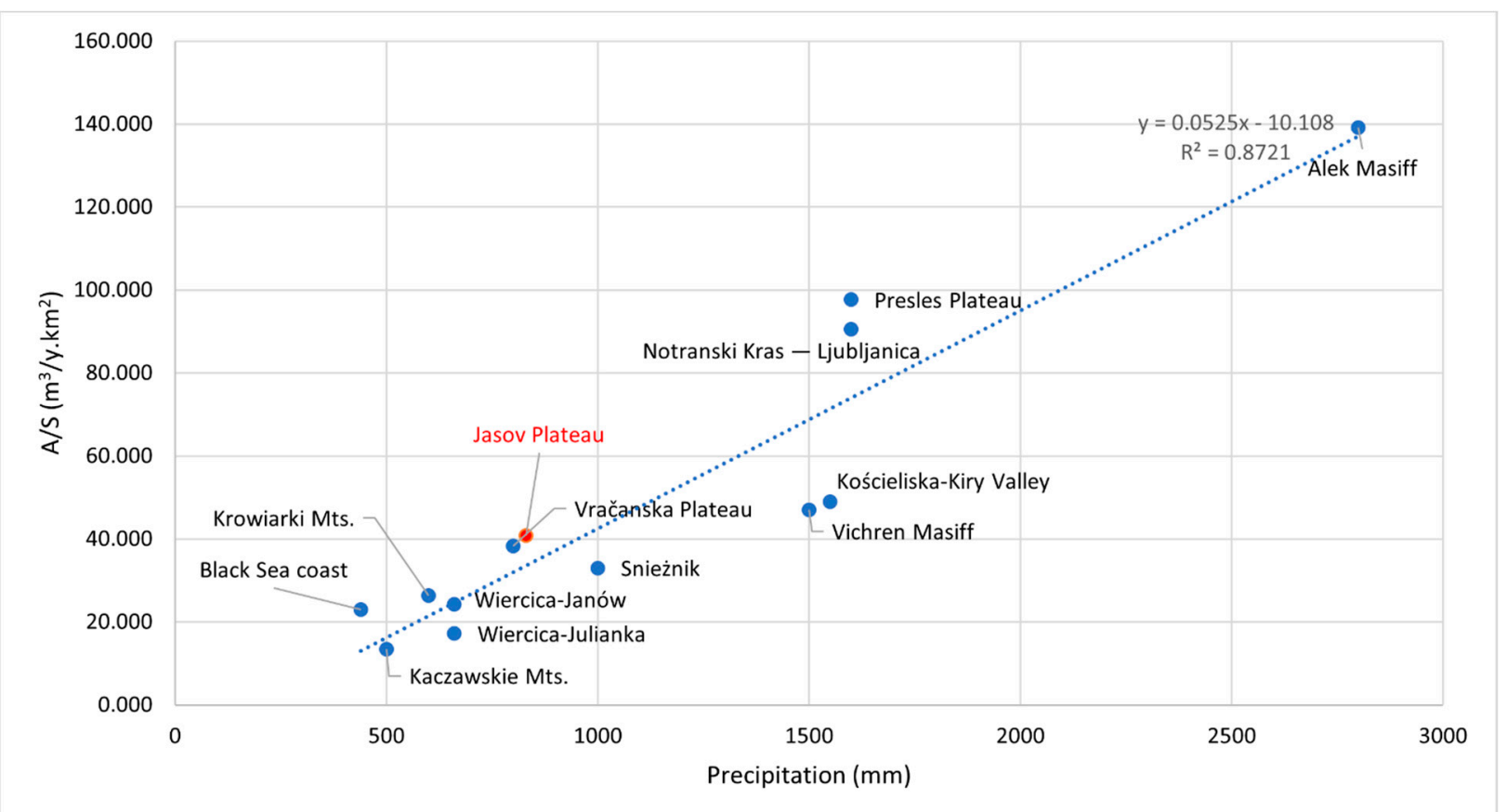

Figure 10. Relationship of precipitation and A/S (ionic runoff/area). Study areas of [5,23] and Slovak Karst, localities described in Table 2.

Based on the chemical composition of liquid precipitation from the territory of Slovakia [58], we can state that the chemistry of precipitation does not affect the chemistry of groundwater in this area. The geographically closest station with such information is Milhostov (80 km from the Jasov Plateau, Table 3).

Table 3. Average content of the total dissolved solids in liquid precipitation for Milhostov station (1983-1994) [58].

\begin{tabular}{lllllllllllllllll}
\hline $\begin{array}{l}\text { Rainfall } \\
(\mathbf{m m})\end{array}$ & $\begin{array}{l}\mathrm{TDS} \\
\boldsymbol{\mu S} / \mathbf{c m}\end{array}$ & $\mathbf{K}$ & $\mathbf{M g}$ & $\mathbf{C a}$ & $\mathrm{CI}$ & $\mathbf{N H}_{\mathbf{4}}$ & $\mathbf{N O}_{3}$ & $\mathbf{S 0}_{\mathbf{4}}$ & $\mathbf{Z n}$ & $\mathbf{F e}$ & $\mathrm{Al}$ & $\mathbf{M n}$ & $\mathbf{F}$ & $\mathbf{H C O}_{3}$ \\
\hline 438.15 .73 & 40.8 & 0.8 & 0.31 & 0.38 & 0.37 & 1.01 & 0.53 & 0.92 & 2.63 & 492 & 0.05 & 0.1 & 18 & 36 & 3.5 \\
\hline
\end{tabular}

The second most significant climatic influence is indirect average annual air temperature (Figure 10), which is closely linked to evapotranspiration and growing season length. 
Since dense vegetation covers almost the entire plain, this has a significant impact on evapotranspiration. In the cold season, the land cover favorability to evaporation is very low. These facts are also confirmed by [56]. Rainwater is retained in the vegetation and soil cover during the growing season, and only a small percentage subsidizes the amount of groundwater. As data from evapotranspiration are available closest to the city of Košice (40 km away and situated at an altitude of $200 \mathrm{~m}$ a.s.1.), we do not directly analyze this factor here.

From the point of view of climatic factors, the Jasov Plateau is closest in character to the nearby localities in Poland and Sniežnik, Krowiarki Mts. and Wiercica River (Figures 10 and 11). However, the results are closest to the area of Vračanska planina in Bulgaria, which has a similar altitude of $800 \mathrm{~m}$ a.s.l., precipitation of $800 \mathrm{~m}$, but also spring discharge $\left(0.55 \mathrm{~m}^{3} \mathrm{~s}^{-1}\right)$.

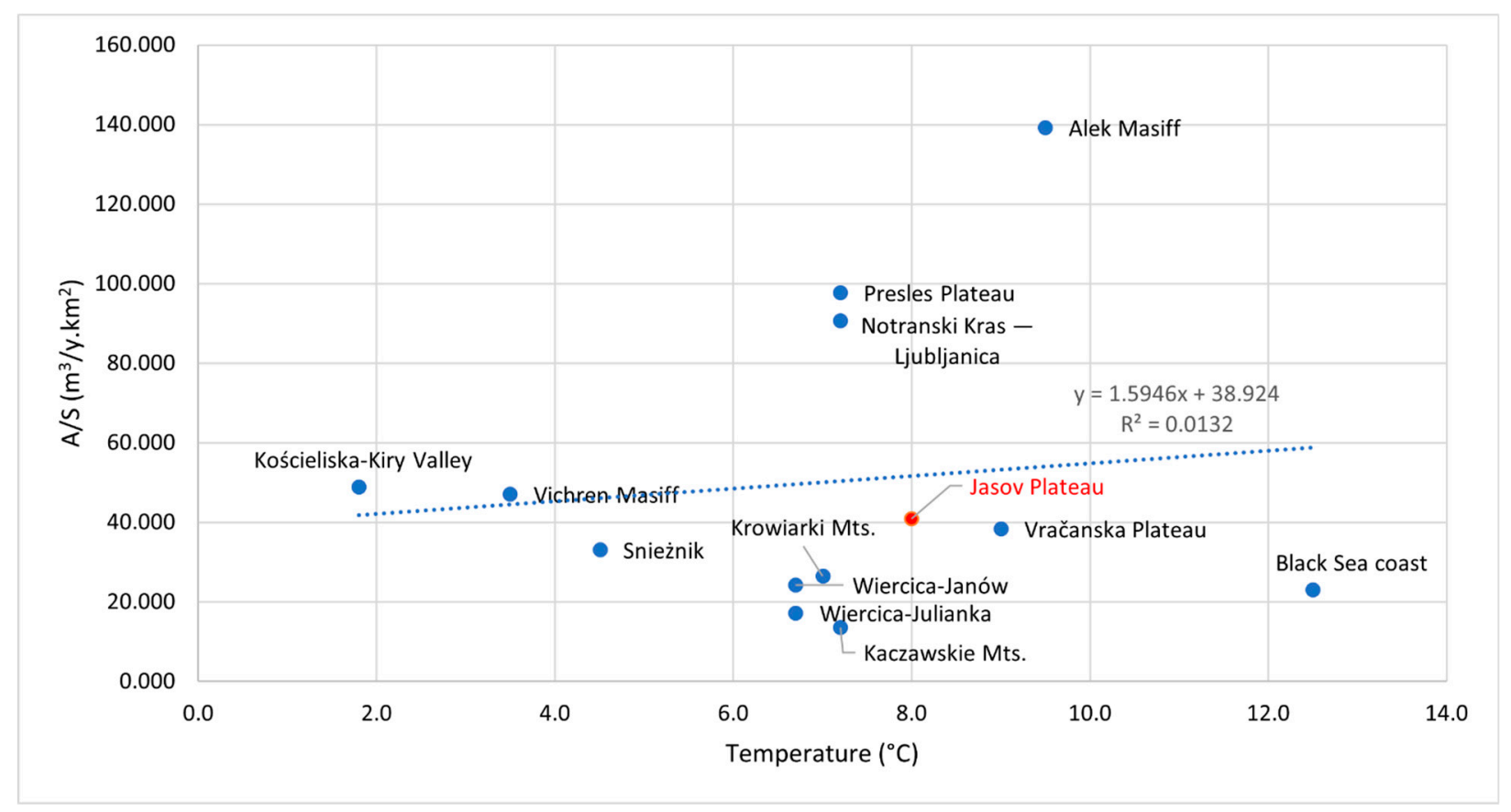

Figure 11. Relationship of air temperature and A/S (ionic runoff/area). Study areas of [5,23] and Slovak Karst, localities described in Table 2.

Carbon dioxide also has a very important role in rock dissolution [57]. Understanding its dynamics and distribution in the subsurface atmosphere of carbonate karst massifs and dissolved $\mathrm{CO}_{2}$ provides important insights into dissolution and precipitation processes, and the role of karst systems in the global carbon cycle [59]. Water is enriched with $\mathrm{CO}_{2}$ mainly in the soil [60], and $\mathrm{CO}_{2}$ availability depends on the type of vegetation cover and the soil temperature. After [61] winter and early spring waters have the greatest effect, due to minimal evapotranspiration and increased dissolution of $\mathrm{CO}_{2}$ in the water due to lower temperature.

Fluctuations in karst groundwater can be very different, and as a consequence different types of surface-groundwater interaction can occur [62]. Some of the factors affecting ionic runoff (and denudation) have different weights in different karst areas. Figure 12 graphically depicts the factors influencing karst spring discharge and mineralization (and thus ionic discharge). 


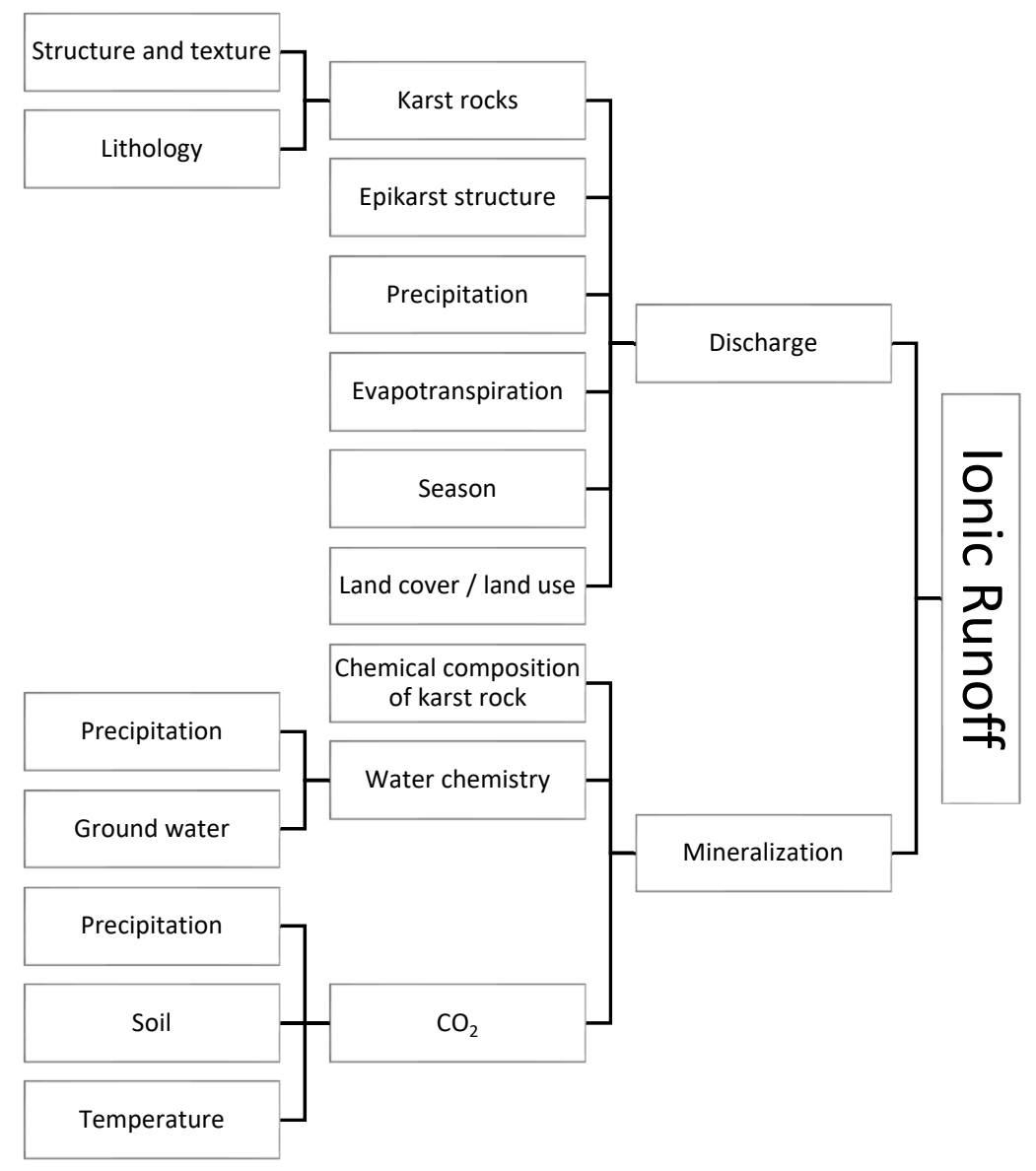

Figure 12. Main factors influencing the ionic runoff in the karst area.

\section{Conclusions}

The ionic runoff method is suitable, especially in areas where it is not possible to precisely delineate the recharge area. It is a relatively simple method, and through data on discharge and mineralization, we can determine the amount of denuded material from such a karst basin, in our case from the entire karst area.

The area of Jasov Plateau in the Slovak Karst belongs to the classical and typical plateau karst areas with most spring outlets at the foothills. These have significantly fluctuating flow rates from $0 \mathrm{~L} / \mathrm{s}$ in summer and autumn up to $192 \mathrm{~L} / \mathrm{s}$ at the Teplica Spring on February 1, 2014. Episodic events during the snow melting and at the same time heavy rain in the spring of 2013 are also known, where the discharge at the Teplica and Drienovec springs reached more than $380 \mathrm{~L} / \mathrm{s}$. The total value of ionic runoff for this area, $40,847 \mathrm{~m}^{3} / \mathrm{y} \cdot \mathrm{km}^{2}$, is comparable with the Vračanska Plateau in Bulgaria, which lies at a similar altitude and with a similar amount of precipitation.

Based on the differences found during our regular measurements, seasonal differences, and in comparison with other European experimental sites, we consider important factors that are related to the climate zone and the character of the karst area. Discharge and its changes during the year are influenced by static factors such as karst rocks (structure, texture, and lithology) and epikarst character. Variable factors are precipitation, evapotranspiration, season, land cover, and land use. The mineralization is influenced by the chemical composition of karst rock and the variability in water chemistry is affected by the chemical composition of precipitation and ground water with fluctuation in $\mathrm{CO}_{2}$ (study of the precipitation chemical composition was not the aim of this study). These also appear to be some of the most important factors and depend on precipitation, soil seasonal changes, and temperature (air and soil), depending on the season. 
Supplementary Materials: The following are available online at https:/ /www.mdpi.com/article/ 10.3390/w13111449/s1. Table S1: Characterization coefficients and saturation index of calcite for monitored springs, Table S2: Statistical evaluation of ionic runoff of the Jasov Plateau springs based on the method of [5].

Author Contributions: Conceptualization, A.G. and I.S.; methodology, A.G., I.S. and L.P.; validation, A.G., I.S., V.S. and L.P.; formal analysis, M.B., E.H. and A.C.; investigation, A.G. and V.S.; data curation, A.G. and L.P.; writing—original draft preparation, A.G. and I.S.; writing—review and editing, A.G. and L.P.; visualization, A.G. and I.S.; supervision, A.G.; funding acquisition, A.G. All authors have read and agreed to the published version of the manuscript.

Funding: This research was funded by VEGA, grant number 1/0798/20, and KEGA, grant number 016UPJŠ-4/2021.

Institutional Review Board Statement: Not applicable.

Informed Consent Statement: Not applicable.

Data Availability Statement: Used data are a part of this study, which is the first summarizing paper from these results. Most of the data are a part of Supplementary Materials.

Acknowledgments: Special thanks to all people who participated in the field expedition measurements.

Conflicts of Interest: The authors declare no conflict of interest.

\section{References}

1. Dreybrodt, W. Processes in Karst Systems: Physics, Chemistry, and Geology; Springer: Berlin, Germany; New York, NY, USA, 1988; Volume 12.

2. Ford, D.C.; Williams, P.W. Karst Geomorphology and Hydrology; Unwin Hyman: London, UK, 1989.

3. White, W.B. Geomorphology and Hydrology of Karst Terrains; Oxford University Press: New York, NY, USA, 1988.

4. Fischer, A.G. Geological time-distance rates-The Bubnoff unit. Geol. Soc. Am. Bull. 1969, 80, 549-551. [CrossRef]

5. Pulina, M. Denudacja Chemiczna na Obszarach Krasu Weglanowego (Sum. Chemical Denudation on the Carbonate Karst Areas); Prace Geograficzne PAN; Ossolineum: Wrocław, Poland, 1974.

6. Corbel, J. Erosion en terrain calcaire-Vitesse d'érosion et morphologie. Ann. Géographie 1959, 68, 97-120. [CrossRef]

7. Gabrovšek, F. On concepts and methods for the estimation of dissolutional denudation rates in karst areas. Geomorphology 2009, 106, 9-14. [CrossRef]

8. Plan, L. Factors controlling carbonate dissolution rates quantified in a field test in the Austrian Alps. Geomorphology 2005, 68, 201-212. [CrossRef]

9. High, C.J.; Hanna, F.K. A method for the direct measurement of erosion on rock surfaces. Br. Geomorphol. Res. Group Tech. Bull. 1970, 5, 1-25.

10. Cucchi, F.; Forti, P.; Ulcigrai, F. Valori di abbassamento per dissoluzione carsiche. Acta Carsol./Karsoslovni Zb. $1994,23,55-62$.

11. Lauritzen, S.E. A Simple Growth Model for Allogenic Pedestals in Glaciated Karst. In Proceedings of the 14th International Congress of Speleology, Athen-Kalamos, Greece, 21-28 August 2005; pp. 1-5.

12. Stone, J.O.H.; Evans, J.M.; Fifield, L.K.; Allan, G.L.; Cresswell, R.G. Cosmogenicchlorine-36 production in calcite by muons. Geochim. Cosmochim. Acta 1998, 62, 433-454. [CrossRef]

13. Smith, D.I.; Newson, M.D. The Dynamics of Solutional and Mechanical Erosion in Limestone Chatchments on the Mendip Hills, Somerset. In Fluvial Porcesses in Instrumented Watersheds; Institute of British Geographers: Lodon, UK, 1974; Special Publication 6; pp. 155-167.

14. Priesnitz, K. Losungsraten und ihre geomorphologische relevanz. Abh. Akad. Wiss. Göttingen, Math. Phys. Kl 1974, 3, 68-84.

15. Gams, I. Faktorji in dinamika korozije na karbonatnih kameninah Slovenskega Dinarskega in Alpskega krasa. Geogr. Vestn. 1967, 38, 11-68.

16. Appelo, C.A.J.; Postma, D. Geochemistry, groundwater and pollution: Rotterdam. AA Balkema 1993, 536, $237-247$.

17. Gabrovšek, F. On denudation rates in karst. Acta Carsol. 2007, 36, 9-14. [CrossRef]

18. Shopov, Y.; Stoykova, D.; Tsankov, L.T.; Marinova, E.; Sauro, U.; Borsato, A.; Cucchi, F.; Forti, P.; Piccini, L.; Ford, D.C.; et al. Past Annual Variations of the Karst Denudation Rates. In Larst, Climate Change and Groundwater; Serie: Hidrogeología y aguas subterráneas; Publicaciones del Instituto Geologico y minero de Espana: Madrid, Spain, 2009; pp. 487-494.

19. Rzonca, B.; Buczyński, S. Intense karst denudation in a crystalline basin with a small share of carbonate rocks (Sudety Mountains, SW Poland). CATENA 2013, 107, 154-164. [CrossRef]

20. Yan, J.; Li, J.; Ye, Q.; Li, K. Concentrations and exports of solutes from surface runoff in Houzhai karst basin, southwest China. Chem. Geol. 2012, 304-305, 1-9. [CrossRef]

21. Pulina, M.; Postnov, I. Kras gipsowy w północno-Zachodniej części Ziemi Nordenskiolda-Zachodni Spitsbgergen. Kras Speleol. 1989, 6, 40-57. 
22. Pulina, M. Grønfjord-Barentsburg. In Proceedings of the Funkcjonowanie Dawnych I Współczesnych Geoekosystemów Spitsbergenu, Poznań-Longyerbyen, Poland, 10-21 July 2003; pp. 173-176.

23. Pulina, M.; Fagundo, J.R. Tropical karst and chemical denudation of western Cuba. Geogr. Pol. 1992, 60, $195-216$.

24. Tsakiris, G.; Spiliotis, M.; Paritsis, S.; Alexakis, D. Assessing the water potential of karstic saline springs by applying a fuzzy approach: The case of Almyros (Heraklion, Crete). Desalination 2009, 237, 54-64. [CrossRef]

25. Himmel, J. Variabilita intenzity krasovění v zóně vertikální cirkulace v podmínkách Moravského krasu. Geolog. Výzk. Mor. Slez. Roce 2006, 1999, 144-149.

26. Himmel, J. Intenzita krasovění vápenců zóny vertikální krasové cirkulace v Moravském krasu. Speleo 2000, 29 , 12-17.

27. Štelcl, O.; Vlček, V.; Panovský, K. Intenzita koroze různých typů karbonátových Hornin v ČSR. Ceskoslov. Kras 1976, 28 , 29-46.

28. Roda, Š.; Rajman, L.; Erdös, M.; Szabová, T. Vznik a Vývoj Sintrových Foriem v Piatich Jaskyniach Slovenského Krasu; Gemerská Vlastivedná Spoločnost': Rimavská Sobota, Slovakia, 1986.

29. Droppa, A. Intenzita korózie krasových tokov v Demänovskej doline (Corrosion intensity of karst streams in the Demänovská Dolina valley). Slov. Kras 1976, 14, 3-30.

30. Droppa, A. Intenzita korózie tokov v Jánskej doline (The intensity of stream corrosion in the Jánska Dolina valley). Slov. Kras 1978, 16, 39-67.

31. Droppa, A. Korózny Účinok Krasových Tokov Na Severnej Strane Nízych Tatier; Slovenský Kras; SMOPAJ: Liptovský Mikuláš, Slovakia, 2012; Supplementum 1.

32. Hochmuth, Z.; Vadelová, I. Výskum kvantitatívnych aspektov povrchovej korózie krasových hornín v Slovenskom raji a Slovenskom krase. Slov. Kras 2010, 48, 241-251.

33. Hochmuth, Z.; Gessert, A. The Jasov Plateau in the Slovak Karst as an Experimental Area for the Denudation Dynamic Research. In Proceedings of the 17th International Congress of Speleology; Australian Speleological Federation: Sydney, Australia, 2017; Volume 2, pp. $38-42$.

34. Sládek, I. Predbežné výsledky výskumu vplyvu obsahu dolomitovej zložky vo vápencoch východnej časti Slovenského krasu na proces krasovej korózie. Geogr. Cassoviensis 2014, 2, 173-180.

35. Peel, M.C.; Finlayson, B.L.; McMahon, T.A. Updated world map of the Köppen-Geiger climate classification. Hydrol. Earth Syst. Sci. 2007, 11, 1633-1644. [CrossRef]

36. Gessert, A. Geomorphology of the Slovak karst (eastern part). J. Maps 2016, 12, 285-288. [CrossRef]

37. Gaál, Ĺ. Geodynamika a Vývoj Jaskýn̆ Slovenského Krasu; Štátna ochrana prírody SR, Správa Slovenských Jaskýň: Banská Bystrica, Slovakia, 2008; ISBN 80-8064-330-X.

38. Hochmuth, Z. Atlas Jaskyne Skalistý Potok; Slovenská Speleologická Spoločnost': Liptovský Mikuláš, Slovakia, 2013.

39. Hochmuth, Z.; Petrvalská, A. Exokarst Forms of the Jasovská Plateau; Ostravská univerzita v Ostravě: Ostrava, Czech Republic, 2010; pp. 15-19.

40. Lešinský, G. Výsledky speleologickej inventarizácie na Jasovskej planine v Slovenskom krase. Slov. Kras 2002, 40, 137-173.

41. Petrvalská, A. Reliéf Jasovskej Planiny v Slovenskom Krase; PJ Šafárik University: Košice, Slovakia, 2014 ; p. 112.

42. Longest Caves of Slovakia. 2020. Available online: https://sss.sk/tabulka-najdlhsich-jaskyn-na-slovensku/ (accessed on 11 May 2011).

43. Climate Atlas of Slovak Republic. Available online: http://klimat.shmu.sk/kas/ (accessed on 18 March 2021).

44. Mello, J.; Pristaš, J.; Reichwalder, P.; Snopko, L.; Vass, D.; Vozárová, A.; Gaál, L'; Hanzel, V.; Hók, J.; Kováč, P. Vysvetlivky Ku Geologickej Mape Slovenského Krasu 1:50,000; Vydavatel'stvo Dionýza Štúra: Bratislava, Slovakia, 1997; ISBN 80-85314-64-9.

45. Zacharov, M. Geologické a tektonické pomery drienovskej Jaskyne v Slovenskom krase. Slov. Kras 2008, 46, 41-52.

46. Podmienky Využívania a Ochrany Podzemných Vôd Slovenského Krasu. In Puklinové a Puklinovo-Krasové Vody a Problémy Ich Ochrany; GÚDŠ: Bratislava, Slovakia, 1984; pp. 107-115.

47. Zacharov, M. Význam regionálnych tektonických štruktúr vo východnej časti Slovenského krasu pre vznik a vývoj jaskýň. Slov. Kras 2012, 50, 11-30.

48. Mello, J.; Elečko, M.; Pristaš, J.; Reichwalder, P.; Snopko, L.; Vass, D.; Vozárová, A. Geologická Mapa Slovenského Krasu 1:50,000; MŽP SR, GS SR: Bratislava, Slovakia, 1996.

49. Šuba, J. Evidencia Vodných Zdrojov a Jej Budovanie. Publ. ČSVTS: Bratislava, Slovakia, 1979; p. 8.

50. Šuba, J. Slovenský Kras a Turnianska Kotlina, Vyhl'adávací Hydrogeologický Prieskum; Manuskript-Archív Geologickej Služby SR: Bratislava, Slovakia, 1973; p. 91.

51. Gessert, A.; Straková, V.; Palcsu, L.; Koltai, G.; Braun, M.; Heim, E.; Czébely, A. Differences in temporal changes of selected water quality parameters on Jasovská planina plateau (Slovak karst, Slovakia). GC 2019, 13, 5-20. [CrossRef]

52. Fl’aková, R.; Ženišová, Z.; Seman, M. Chemická Analýza Vody v Hydrogeológii; Slovenská Asociácia Hydrogeológov: Bratislava, Slovakia, 2010; ISBN 978-80-969342-8-7.

53. Parkhurst, D.L.; Appelo, C.A.J. Description of Input and Examples for PHREEQC Version 3: A Computer Program for Speciation, Batch-Reaction, One-Dimensional Transport, and Inverse Geochemical Calculations; US Geological Survey: Lakewood, CO, USA, 2013.

54. Lewin, J.; Woodward, J. The Physical Geography of the Mediterranean; Oxford University Press: Oxford, UK, 2009; ISBN 978-0-19-926803-0.

55. Palcsu, L.; Gessert, A.; Túri, M.; Kovács, A.; Fúto, I.; Orsovszki, J.; Puskás-Preszner, A.; Temovski, M.; Koltai, G. Long-term time series of environmental tracers to reveal recharge and discharge conditions in shallow karst aquifers in Hungary and Slovakia. J. Hydrol. Reg. Stud.. Submitted. 
56. Stroj, A.; Briški, M.; Oštrić, M. Study of groundwater flow properties in a karst system by coupled analysis of diverse environmental tracers and discharge dynamics. Water 2020, 12, 2442. [CrossRef]

57. Lánczos, T.; Filipčíková, N. Speleogenetický význam $\mathrm{CO}_{2}$ pre vývoj vybraných jaskýn̆ plaveckého krasu v Malých Karpatoch. Slov. Kras 2017, 55, 5-22.

58. Malík, P.; Michalko, J.; Rapant, S.; Scherer, S. Izotopy síry v zimných zrážkach na území Slovenska. Podzemná Voda 2000, 6, 174-184.

59. Kukuljan, L.; Gabrovšek, F.; Covington, M.D.; Johnston, V.E. CO2 dynamics and heterogeneity in a cave atmosphere: Role of ventilation patterns and airflow pathways. 2021. [CrossRef]

60. Droppa, A. Vplyv Ročných Období Na Koróziu Demänovského Krasu. In Proceedings of the Zborník Referátov z Vedecké Konferencie, Liptovský Mikuláš, Slovakia, 10-11 October 1995; pp. 63-70.

61. Himmel, J. Efektivnost infiltrace atmosférických srážek do podzemních vod v Podmínkách Moravského krasu během průměrného roku. Speleo 2000, 30, 19-25.

62. Gabrovšek, F.; Peric, B. Monitoring the flood pulses in the epiphreatic zone of karst aquifers: The case of Reka river system, Karst plateau, SW Slovenia. Acta Carsol. 2006, 35. [CrossRef] 